\title{
Seasonal hydrology drives rapid shifts in the flux and composition of dissolved and particulate organic carbon and major and trace ions in the Fraser River, Canada
}

\author{
B. M. Voss ${ }^{1,2, a}$, B. Peucker-Ehrenbrink ${ }^{1,3}$, T. I. Eglinton ${ }^{4}$, R. G. M. Spencer ${ }^{5,6}$, E. Bulygina $^{6}$, V. Galy ${ }^{1}$, \\ C. H. Lamborg ${ }^{1,7}$, P. M. Ganguli ${ }^{1}$, D. B. Montluçon ${ }^{4}$, S. Marsh ${ }^{3}$, S. L. Gillies ${ }^{3}$, J. Fanslau ${ }^{1,3,6}$, A. Epp ${ }^{1,3}$, and \\ R. Luymes ${ }^{1,3}$ \\ ${ }^{1}$ Woods Hole Oceanographic Institution, 360 Woods Hole Road, Woods Hole, MA 02543, USA \\ ${ }^{2}$ Massachusetts Institute of Technology, 77 Massachusetts Avenue, Cambridge, MA 02139, USA \\ ${ }^{3}$ University of the Fraser Valley, 33844 King Road, Abbotsford, BC V2S 7M7, Canada \\ ${ }^{4}$ Eidgenössische Technische Hochschule, Sonneggstrasse 5, 8092 Zürich, Switzerland \\ ${ }^{5}$ Florida State University, 600 West College Avenue, Tallahassee, FL 32306, USA \\ ${ }^{6}$ Woods Hole Research Center, 149 Woods Hole Road, Falmouth, MA 02540, USA \\ ${ }^{7}$ University of California Santa Cruz, 1156 High Street, Santa Cruz, CA 95064, USA \\ anow at: US Geological Survey, 3215 Marine Street, Suite E-127, Boulder, CO 80303, USA
}

Correspondence to: B. M. Voss (bvoss@whoi.edu)

Received: 27 March 2015 - Published in Biogeosciences Discuss.: 21 May 2015

Accepted: 2 September 2015 - Published: 1 October 2015

\begin{abstract}
Rapid changes in the volume and sources of discharge during the spring freshet lead to pronounced variations in biogeochemical properties in snowmelt-dominated river basins. We used daily sampling during the onset of the freshet in the Fraser River (southwestern Canada) in 2013 to identify rapid changes in the flux and composition of dissolved material, with a focus on dissolved organic matter (DOM). Previous time series sampling (at twice monthly frequency) of dissolved inorganic species in the Fraser River has revealed smooth seasonal transitions in concentrations of major ions and tracers of water and dissolved load sources between freshet and base flow periods. In contrast, daily sampling reveals a significant increase in dissolved organic carbon (DOC) concentration (200 to $550 \mu \mathrm{mol} \mathrm{L}^{-1}$ ) occurring over a matter of days, accompanied by a shift in DOM optical properties, indicating a transition towards higher molecular weight, more aromatic DOM composition. Comparable changes in DOM composition, but not concentration, occur at other times of year, underscoring the role of seasonal climatology in DOM cycling. A smaller data set of total and dissolved $\mathrm{Hg}$ concentrations also showed variability during the spring freshet period, although dissolved $\mathrm{Hg}$ dynamics appear to be driven by factors beyond DOM as
\end{abstract}

characterized here. The time series records of DOC and particulate organic carbon (POC) concentrations indicate that the Fraser River exports $0.25-0.35 \%$ of its annual basin net primary productivity. The snowmelt-dominated hydrology, forested land cover, and minimal reservoir impoundment of the Fraser River may influence the DOC yield of the basin, which is high relative to the nearby Columbia River and of similar magnitude to that of the Yukon River to the north. Anticipated warming and decreased snowfall due to climate changes in the region may cause an overall decrease in DOM flux from the Fraser River to the coastal ocean in coming decades

\section{Introduction}

Export of riverine organic matter $(\mathrm{OM})$ to the coastal ocean contributes significantly to heterotrophic metabolism in coastal marine ecosystems, supplying approximately 0.5 $\mathrm{Pg}$ of organic carbon (OC) per year, approximately half in dissolved and half in particulate form (e.g., Cai, 2011). A significant portion of terrestrial $\mathrm{OC}$ is metabolized and transformed by biological activity within terrestrial aquatic 
ecosystems (Cole and Caraco, 2001; Battin et al., 2009; Aufdenkampe et al., 2011), and the molecular composition of $\mathrm{OM}$ is thought to exert controls on its bioavailability to in situ microbial communities (e.g., Sun et al., 1997; Fellman et al., 2009; Stepanauskas et al., 2005). The concentration and composition of OM in freshwater systems also has implications for mobilization and speciation of mercury $(\mathrm{Hg})$, an important element for its potential toxicity, particularly when converted to monomethyl $\mathrm{Hg}$ and biomagnified within food webs (Fleck et al., 2014; Zheng et al., 2012). Comprehensive time-series data sets for fluvial systems, including nutrients, dissolved major elements, water isotopes, and suspended sediments in addition to DOM (dissolved organic matter) properties are rare (e.g., Dornblaser and Striegl, 2007, 2009; Spencer et al., 2012; Walling and Foster, 1975; Bagard et al., 2011), yet are necessary to establish a robust foundation for distinguishing biogeochemical from hydrologic and physical processes.

Rapid changes in riverine DOC concentrations are often associated with variations in discharge on timescales of hours to weeks. Such hydrologic effects on DOC concentration have been observed in large Arctic rivers during the spring freshet (Holmes et al., 2012; Mann et al., 2012; Wickland et al., 2012), as well as in tropical catchments experiencing wet-season flushing of surface soils (Spencer et al., 2010; Laraque et al., 2013), and in small streams and headwater catchments dominated by episodic rain or snowmelt events (Sandford et al., 2013; Raymond and Saiers, 2010; Lloret et al., 2013; Fellman et al., 2009; Battin, 1998). In these settings, the composition of DOM is often observed to change significantly, as changing hydrologic flow paths draw upon different DOM pools (Striegl et al., 2005; Mann et al., 2012; Spencer et al., 2010). The bulk concentration of DOC in the Fraser River has been investigated through water quality monitoring by Environment Canada (Swain, 2007); however, more detailed information about the composition of Fraser River DOM and its controlling processes are lacking. DOC constitutes the larger pool of OC delivered to the coastal ocean by the Fraser River, at concentrations $\sim 5$ times higher than POC during the spring freshet when suspended sediment concentrations peak, and $\sim 30$ times higher during low discharge conditions.

The residence time of OC derived from fresh litterfall in soils depends on its initial composition and environmental conditions, and varies between less than 1 year to hundreds or thousands of years (Mills et al., 2014). DOM that enters stream channels under base flow conditions generally originates from deeper soil layers, where organic matter has been exposed to microbial degradation and potential sorption surfaces for a long time relative to fresh litter leachates in shallow soil layers (Hope et al., 1994; Easthouse et al., 1992; Michalzik et al., 2003). Freshet DOM, which derives largely from overland flow and more extensive soil inundation, is composed of organic matter that has been exposed to soil microbial communities for a shorter time than deep soil DOM
(Wickland et al., 2007; O’Donnell et al., 2010). This distinction is evident in the increase in DOC radiocarbon content across the freshet transition in large Arctic rivers, as shallow soil DOC containing bomb ${ }^{14} \mathrm{C}$ is released during spring thaw (Raymond et al., 2007). This relatively fresh DOM has also been identified as more susceptible to microbial degradation (Holmes et al., 2008; Mann et al., 2012), and is therefore a more potent source of metabolic fuel to coastal ocean ecosystems and thus a potential flux of $\mathrm{CO}_{2}$ to the atmosphere.

The Fraser River is a large, mountainous river basin in southwestern Canada. Total basin area is $233000 \mathrm{~km}^{2}$ and average annual discharge is $112 \mathrm{~km}^{3} \mathrm{a}^{-1}$ (Meybeck and Ragu, 2012). The basin is largely forested and experiences relatively little anthropogenic modification in the form of dams, channelization, or land cover alteration for a basin of its size and latitude. The time series record of DOC concentration in the Fraser River from Environment Canada (Swain, 2007) has not been analyzed and published in peer-reviewed literature, and we are not aware of any published studies of DOM composition in the Fraser River. Several aspects of the basin (e.g., physiographic features, hydrologic regime and climatic setting) suggest it may exhibit somewhat different behavior from established paradigms for large Arctic rivers and small streams. First, a number of the major Arctic rivers (Yenisey, Ob', Lena, Kolyma, Mackenzie) generally have catchments that drain northward and narrow flowing downstream (a "northward funnel" shape), triggering a sudden peak in total basin discharge in the downstream portions of these basins during spring melt. In contrast, the southwarddraining orientation of the Fraser basin and northward migration of spring warming mutes the amplitude and prolongs the duration of the freshet. Second, the freshet hydrograph in the Fraser River is often punctuated by pauses in melting due to cold intervals and/or precipitation pulses from spring storms, which, due to the presence of mountain ranges, can exert longitudinal differences across the basin. The resulting stepwise character of the freshet may lead to a more complex transition between base flow and freshet DOC concentrations, and a less extreme peak DOC concentration. Third, the smaller size of the Fraser basin relative to large Arctic rivers also means that storm events typically impact large portions of the basin, causing significant short-term increases in total discharge. Fourth, the lack of extensive permafrost in the Fraser basin excludes significant inputs from a potential pool of aged soil DOM during late spring and summer months. Finally, in small streams, storm-driven discharge events are short-lived and may deliver fresh DOM to stream channels more efficiently than the long, relatively gradual rising limb of the spring freshet in the Fraser River.

A consequence of variability in DOM concentration and composition in freshwaters is the potential for dynamic behavior of dissolved Hg. Due to the strong affinity of dissolved $\mathrm{Hg}$ for DOM, especially reduced organosulfur moieties (Haitzer et al., 2002, 2003; Gerbig et al., 2011), con- 
centrations of DOC and total dissolved $\mathrm{Hg}$ are typically positively correlated in natural waters (Schuster et al., 2011; Dittman et al., 2010; Burns et al., 2013; Demers et al., 2010). We are not aware of any $\mathrm{Hg}$ observations in the main stem Fraser River by federal or provincial government agencies, although $\mathrm{Hg}$ monitoring has been recommended (MacDonald et al., 2011). Mercury concentrations in water and fish tissue are not presently found at levels deemed unfit for human consumption; however, it is a health concern for the Fraser River fisheries and individuals who subsist on diets rich in fish (Cohen, 2012; Kelly et al., 2008). Potential sources of $\mathrm{Hg}$ within the Fraser basin include urban and industrial point sources (e.g., sewage effluent, paper pulp mills), atmospheric deposition (particularly aerosols derived from coal combustion in east Asia), and mobilization of legacy $\mathrm{Hg}$ contamination from placer gold mining (including hydraulic mining in some areas), which was widespread in the central portion of the basin in the 1850s-1910s. Given the major role of rivers in global surface cycling of $\mathrm{Hg}$ (Amos et al., 2014), it is important to constrain the flux of $\mathrm{Hg}$ from this regionally significant river basin.

In this study we examine how (1) rapid changes in discharge impact DOC load during the early stages of the spring freshet; (2) hydrology influences changes in DOC flux and composition throughout the year; and (3) DOM and suspended sediment dynamics influence the $\mathrm{Hg}$ load of the Fraser River. The spring freshet is a critical period to quantify, as it is responsible for the bulk of total annual fluxes of many constituents, including DOC and suspended sediment (Swain, 2007). Given the ongoing and anticipated changes in hydrological conditions in the Fraser basin under a warming climate - particularly an increase in net annual and winter precipitation, a shift towards more rain-dominated relative to snow-dominated precipitation, and a corresponding decrease in snowpack, and an earlier onset to the spring freshet (Morrison et al., 2002; Déry et al., 2012; Shrestha et al., 2012; Riche et al., 2014) - understanding freshet biogeochemical dynamics under present conditions is critical to detecting future changes and anticipating their consequences.

\section{Methods}

\subsection{Discharge and historical data}

Continuous discharge and water temperature information (5 min frequency) were obtained from the Environment Canada Water Office online real-time hydrologic data source (http://www.wateroffice.ec.gc.ca). The record used was the station at Hope $\left(08 \mathrm{MF} 005 ; 49.381^{\circ} \mathrm{N},-121.451^{\circ} \mathrm{E}\right)$, which is $\sim 100 \mathrm{~km}$ upstream of our sampling location at Fort Langley $\left(49.172^{\circ} \mathrm{N},-122.577^{\circ} \mathrm{E}\right.$; Fig. 1$)$, and the farthest downstream station for which gauge height is not influenced by tides. Discharge at Fort Langley is 10-20\% higher than at Hope (due mainly to input from the Harrison River), and wa- ter temperature is $\sim 1.5^{\circ} \mathrm{C}$ higher. The discharge and water temperature records for the study year 2013 are shown in Fig. S1 in the Supplement.

Historical Fraser River DOC concentration data at Hope (1997-2014, station BC08MF0001) were obtained from Environment Canada Pacific Yukon Freshwater Quality Monitoring and Surveillance online data repository (http://aquatic. pyr.ec.gc.ca/). A portion of this record is presented with sampling and analytical information by Swain (2007). Average DOC loads and discharge-weighted average DOC concentrations were calculated from time series records using the LoadEst program (Runkel et al., 2004) as described previously by Voss et al. (2014).

\subsection{Sample collection and basic water chemistry}

The data presented here include Fraser River samples collected during the early portion of the 2013 spring freshet (Table 1), and a DOM-specific data set for samples collected between June 2011 and September 2013 (Table 2). During the 2013 early freshet (26 March to 22 April), discrete samples for basic water chemistry, SPM concentration, and DOM properties were collected daily, while samples for $\mathrm{Hg}$ were collected every 4-5 days. The longer record of DOM properties (2011-2013) constitutes samples collected approximately twice monthly. No field duplicates or blanks were collected for chemical analyses.

Basic water properties were determined with a handheld multiparameter probe (YSI Professional Plus). The probe was equipped with sensors for water temperature $\left({ }^{\circ} \mathrm{C}\right)$, conductivity $\left(\mu \mathrm{S} \mathrm{cm}^{-1}\right), \mathrm{pH}$, and dissolved oxygen (DO, $\mathrm{mg} \mathrm{O}_{2} \mathrm{~L}^{-1}$ ). DO and $\mathrm{pH}$ probes were calibrated according to manufacturer specifications approximately every 5 days.

Samples were collected from a floating dock, $\sim 5 \mathrm{~m}$ from the river bank, where the water depth is $\sim 6 \mathrm{~m}$. All samples for concentrations of dissolved species were collected by inline filtration (Pall AcroPak 500 Supor Membrane, $0.2 \mu \mathrm{m}$ pore size with $0.8 \mu \mathrm{m}$ pre-filter) of surface water directly into pre-cleaned vials, which were rinsed three times with filtered sample water before filling. Therefore, all results for "dissolved" constituents represent material that is $<0.2 \mu \mathrm{m}$. Sampling and analytical methods for most types of samples are described in detail by Voss et al. (2014), therefore the following methods descriptions are abbreviated.

Nutrient samples were collected in pre-cleaned $20 \mathrm{~mL}$ polyethylene scintillation vials and stored frozen until analysis. Analyses for dissolved $\mathrm{NO}_{3}+\mathrm{NO}_{2}, \mathrm{NH}_{4}, \mathrm{PO}_{4}$, and $\mathrm{SiO}_{2}$ were performed on an AutoAnalyzer (Lachat QuickChem 8000) with standard US Environmental Protection Agency-certified spectrophotometric methods and calibrated using standard reference material MOOS-2 (National Research Council Canada). Instrumental detection was $<0.05 \mu \mathrm{mol} \mathrm{L}{ }^{-1}$ for all nutrients.

Samples for dissolved major cations ( $\mathrm{Ca}, \mathrm{Mg}, \mathrm{Na}, \mathrm{K})$ and anions $\left(\mathrm{Cl}, \mathrm{SO}_{4}\right)$ were collected in pre-cleaned $125 \mathrm{~mL}$ high- 

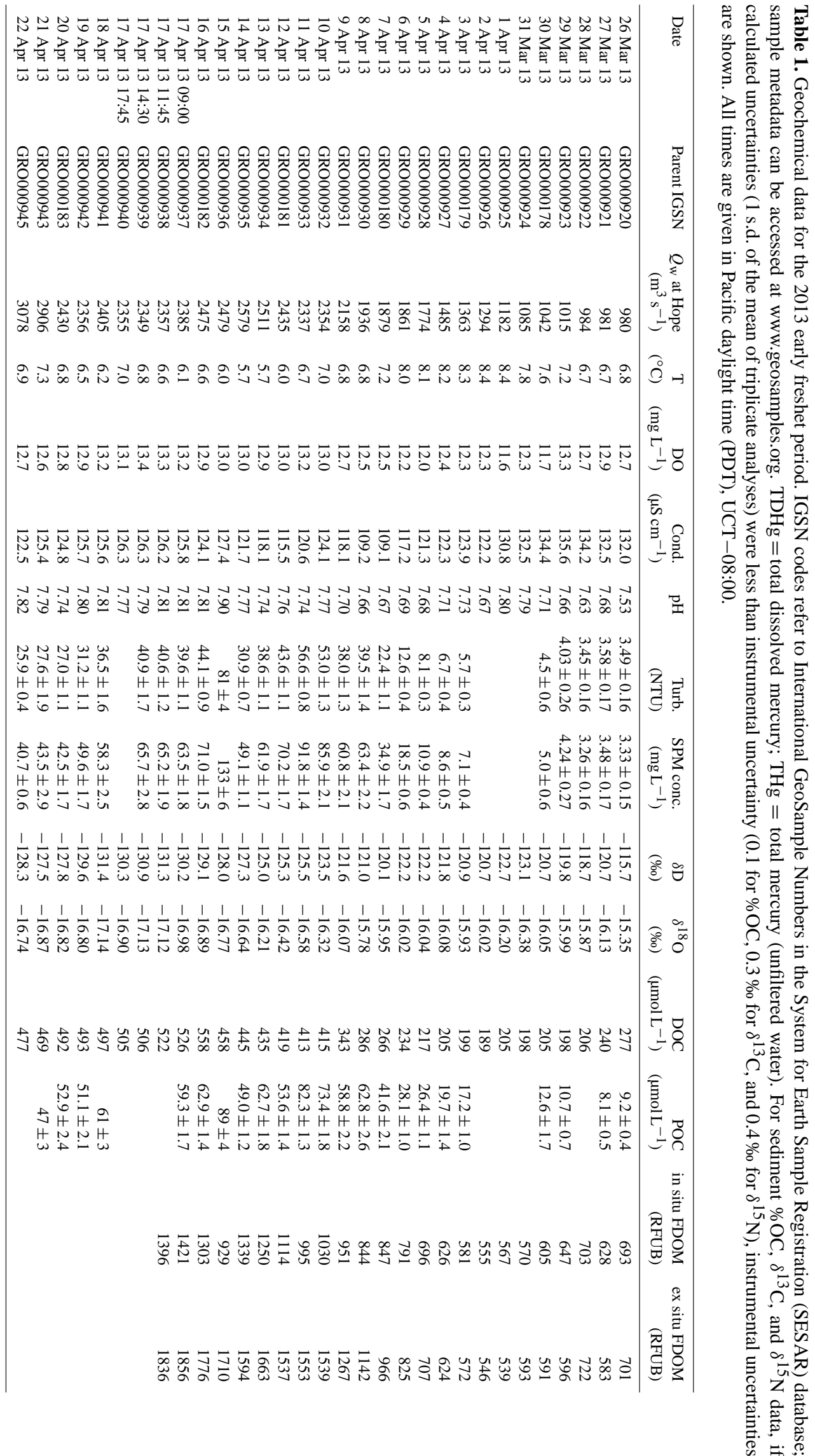


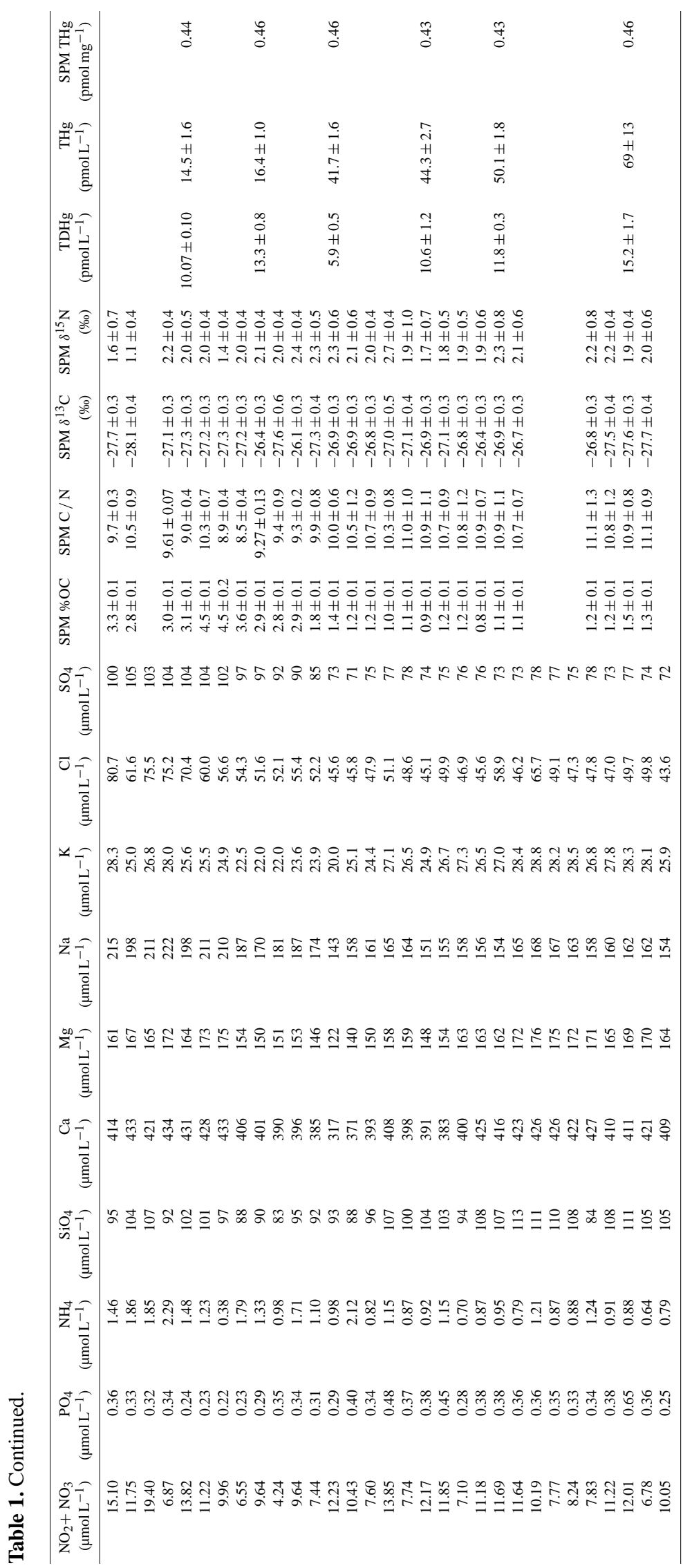




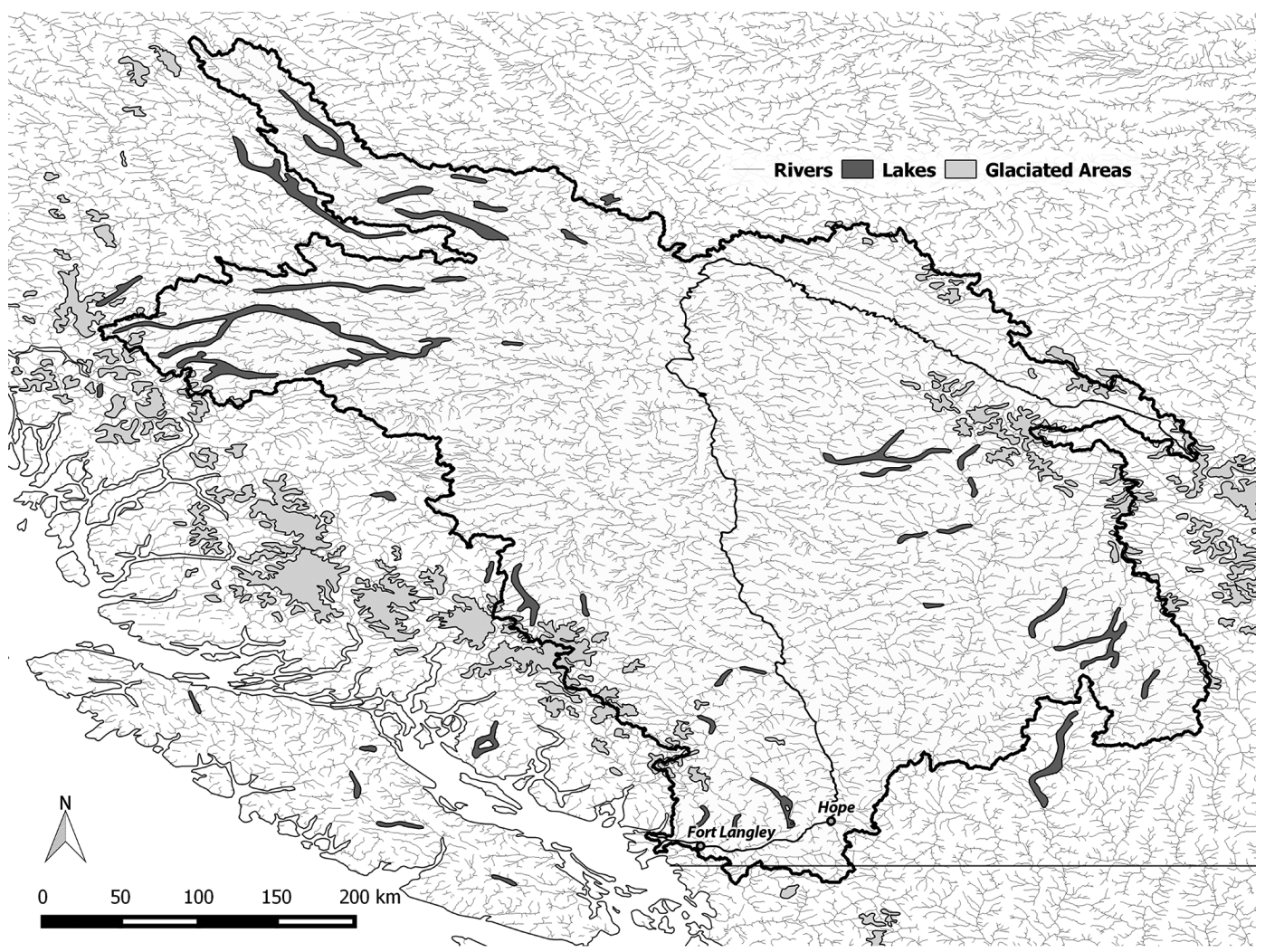

Figure 1. The Fraser River basin, highlighting lakes (natural and man-made; dark grey) and glaciated areas (light grey). Samples were collected at Fort Langley and discharge data (from Environment Canada) are from Hope. River contours and watershed boundaries provided by HydroSHEDS; lake and glacier outlines are derived from the Digital Chart of the World and accessed through Natural Earth Data (http://www.naturalearthdata.com).

density polyethylene bottles. Cation concentrations were determined using a Thermo Scientific Element2 single collector inductively coupled plasma mass spectrometer, based on a standard curve of natural river water standard reference material SLRS-5 (National Research Council Canada). Anion concentrations were determined using a Dionex ion chromatograph with an anion column (AS15, $4 \mathrm{~mm}$, with ASRS suppressor), based on a standard curve of a mixture of SpecPure ion chromatography standards (Alfa Aesar). No preservative was added to major cation and anion samples after collection, and samples were stored at room temperature until analysis. Instrumental precisions and accuracies for cation and anion concentrations were $<5 \%$ (with the exception of accuracy for $\mathrm{Ca}$, which was $5.3 \%$; Voss et al., 2014).

Samples for stable isotope compositions of water were collected by filling $4 \mathrm{~mL}$ glass vials with filtered water without head space. Hydrogen $(\delta \mathrm{D})$ and oxygen $\left(\delta^{18} \mathrm{O}\right)$ isotope compositions were measured on a Picarro L2120-I cavity ringdown spectrometer. Measured values were calibrated using secondary standards (mean \pm 1 s.d.: Mediterranean Sea water, $\delta \mathrm{D} 8.12 \pm 0.30 \% o, \delta^{18} \mathrm{O} 0.95 \pm 0.05 \%$; Jungfrau water, $\delta \mathrm{D}-160.28 \pm 0.21 \% \circ, \delta^{18} \mathrm{O}-22.50 \pm 0.06 \%$; Zürich water, $\delta \mathrm{D}-75.57 \pm 0.19 \%, \delta^{18} \mathrm{O}-10.62 \pm 0.04 \%$ ) , which were calibrated against standard reference materials SLAP2, GISP, and VSMOW2 (International Atomic Energy Agency). Precisions for $\delta \mathrm{D}$ and $\delta^{18} \mathrm{O}$ were 0.3 and $0.03 \%$, respectively; accuracies were 1.0 and $0.07 \%$.

\subsection{Turbidity and suspended sediment concentration}

An optical nephelometer (LaMotte, 2020-WE) was used to determine turbidity (measured in normalized turbidity units, NTU). The nephelometer was calibrated before each measurement with solutions of known turbidity $(0,1.0$, and $10.0 \mathrm{NTU})$. A $20 \mathrm{~mL}$ surface water grab sample was collected in a glass vial and allowed to equilibrate to ambient air temperature. Vial walls were dried and wiped thoroughly with a Kimwipe, and the vial was rolled and gently inverted to resuspend particles before analysis. At least six readings were averaged for each sample to account for measurement variability.

To transform turbidity measurements into concentrations of suspended particulate matter (SPM), nephelometer readings were complemented with weighed sediment masses from filtered water samples. Large volume surface wa- 
Table 2. Two-year record of DOC concentration and optical properties of the Fraser River main stem at Fort Langley. Sampling in 2012 was not at sufficiently high frequency to capture the freshet pulse of DOC. IGSN codes refer to International GeoSample Numbers in the System for Earth Sample Registration (SESAR) database; sample metadata can be accessed at www.geosamples.org.

\begin{tabular}{|c|c|c|c|c|c|c|}
\hline Date & IGSN & $\begin{array}{r}\text { DOC } \\
(\mu \mathrm{mol} \mathrm{L}-1)\end{array}$ & $\begin{array}{r}a_{254} \\
\left(\mathrm{~m}^{-1}\right)\end{array}$ & $\begin{array}{r}\mathrm{SUVA}_{254} \\
\left(\mathrm{~L} \mathrm{mgC}^{-1} \mathrm{~m}^{-1}\right)\end{array}$ & $a_{250}: a_{365}$ & $S_{\mathrm{R}}$ \\
\hline 21 Apr 2011 & GRO000128 & 532 & & & & \\
\hline 3 Маy 2011 & GRO000129 & 733 & & & & \\
\hline 10 May 2011 & GRO000130 & 830 & & & & \\
\hline 13 May 2011 & GRO000131 & 671 & & & & \\
\hline 25 May 2011 & GRO000133 & 601 & & & & \\
\hline 3 Jun 2011 & GRO000135 & 457 & & & & \\
\hline 7 Jun 2011 & GRO000076 & 386 & & & & \\
\hline 28 Jun 2011 & GRO000140 & 265 & 19.37 & 2.64 & 6.45 & 0.98 \\
\hline 8 Jul 2011 & GRO000142 & 282 & 20.90 & 2.68 & 6.38 & 0.95 \\
\hline 15 Jul 2011 & GRO000143 & 364 & 28.18 & 2.80 & 5.92 & 0.87 \\
\hline 19 Jul 2011 & GRO000144 & 339 & 28.32 & 3.02 & 6.06 & 0.95 \\
\hline 29 Jul 2011 & GRO000145 & 335 & 26.91 & 2.90 & 5.91 & 0.95 \\
\hline 26 Sep 2011 & GRO000155 & 193 & 12.65 & 2.37 & 6.60 & 1.11 \\
\hline 14 Oct 2011 & GRO000156 & 242 & 17.43 & 2.61 & 6.03 & 1.02 \\
\hline 25 Oct 2011 & GRO000157 & 256 & 16.69 & 2.36 & 6.89 & 0.97 \\
\hline 26 Oct 2011 & GRO000158 & 250 & 16.87 & 2.44 & 6.58 & 1.04 \\
\hline 31 Oct 2011 & GRO000159 & 275 & 17.15 & 2.25 & 7.91 & 0.86 \\
\hline 15 Nov 2011 & GRO000160 & 318 & 18.28 & 2.08 & 8.12 & 0.87 \\
\hline 28 Nov 2011 & GRO000161 & 254 & 19.88 & 2.83 & 5.98 & 0.92 \\
\hline 11 Jan 2012 & GRO000163 & 237 & 22.52 & 3.43 & 6.38 & 0.93 \\
\hline 10 Feb 2012 & GRO000165 & 217 & 20.13 & 3.35 & 6.53 & 1.01 \\
\hline 18 May 2012 & GRO000168 & 352 & 35.67 & 3.67 & 5.50 & 0.92 \\
\hline 13 Jun 2012 & GRO000220 & 299 & 28.89 & 3.49 & 5.84 & 0.89 \\
\hline 22 Jun 2012 & GRO000207 & 280 & 26.92 & 3.47 & 5.78 & 0.88 \\
\hline 29 Jun 2012 & GRO000169 & 207 & 19.26 & 3.37 & 6.45 & 0.94 \\
\hline 5 Jul 2012 & GRO000170 & 200 & 18.28 & 3.30 & 6.54 & 0.96 \\
\hline $13 \mathrm{Jul} 2012$ & GRO000171 & 176 & 16.33 & 3.35 & 6.56 & 0.98 \\
\hline 27 Jul 2012 & GRO000222 & & 14.87 & & 6.15 & 1.10 \\
\hline 17 Aug 2012 & GRO000239 & & 13.34 & & 7.05 & 1.11 \\
\hline 7 Sep 2012 & GRO000172 & & 14.48 & & 6.46 & 1.17 \\
\hline 21 Sep 2012 & GRO000221 & & 14.97 & & 6.64 & 1.11 \\
\hline 5 Oct 2012 & GRO000223 & & 13.33 & & 6.67 & 1.11 \\
\hline 18 Oct 2012 & GRO000173 & & 17.40 & & 5.72 & 1.00 \\
\hline $12 \operatorname{Jan} 2013$ & GRO000218 & & 23.58 & & 5.49 & 0.85 \\
\hline 2 Feb 2013 & GRO000174 & 266 & 21.02 & 2.85 & 5.82 & 0.92 \\
\hline 9 Feb 2013 & GRO000175 & 248 & 22.55 & 3.28 & 5.46 & 0.89 \\
\hline 16 Mar 2013 & GRO000176 & 242 & 23.97 & 3.59 & 5.21 & 0.86 \\
\hline 23 Mar 2013 & GRO000177 & 209 & 17.69 & 3.06 & 5.88 & 0.92 \\
\hline 27 Mar 2013 & GRO000921 & 240 & 17.02 & 2.56 & 5.98 & 1.04 \\
\hline 28 Mar 2013 & GRO000922 & 206 & 18.76 & 3.29 & 5.80 & 0.94 \\
\hline 29 Mar 2013 & GRO000923 & 198 & 19.56 & 3.57 & 5.62 & 0.96 \\
\hline 30 Mar 2013 & GRO000178 & 205 & 18.66 & 3.29 & 5.73 & 0.99 \\
\hline 31 Mar 2013 & GRO000924 & 198 & 18.47 & 3.37 & 5.72 & 0.98 \\
\hline 1 Apr 2013 & GRO000925 & 205 & 17.70 & 3.13 & 5.98 & 0.98 \\
\hline 2 Apr 2013 & GRO000926 & 189 & 20.60 & 3.94 & 5.34 & 1.07 \\
\hline 3 Apr 2013 & GRO000179 & 199 & 19.92 & 3.62 & 5.58 & 1.04 \\
\hline 4 Apr 2013 & GRO000927 & 205 & 25.96 & 4.58 & 5.49 & 1.11 \\
\hline 5 Apr 2013 & GRO000928 & 217 & 21.23 & 3.54 & 5.51 & 0.99 \\
\hline 6 Apr 2013 & GRO000929 & 234 & 25.40 & 3.93 & 5.38 & 1.02 \\
\hline 7 Apr 2013 & GRO000180 & 266 & 32.65 & 4.44 & 5.30 & 1.06 \\
\hline 8 Apr 2013 & GRO000930 & 286 & 29.12 & 3.68 & 5.48 & 0.89 \\
\hline 9 Apr 2013 & GRO000931 & 343 & 34.35 & 3.62 & 5.52 & 0.88 \\
\hline 10 Apr 2013 & GRO000932 & 415 & 41.05 & 3.58 & 5.64 & 0.87 \\
\hline 11 Apr 2013 & GRO000933 & 413 & 52.53 & 4.60 & 4.94 & 0.99 \\
\hline 12 Apr 2013 & GRO000181 & 419 & 47.00 & 4.05 & 5.18 & 0.93 \\
\hline 13 Apr 2013 & GRO000934 & 435 & 51.81 & 4.31 & 5.08 & 0.94 \\
\hline 14 Apr 2013 & GRO000935 & 445 & 44.52 & 3.62 & 5.42 & 0.86 \\
\hline 15 Apr 2013 & GRO000936 & 458 & 49.14 & 3.88 & 5.28 & 0.90 \\
\hline 16 Apr 2013 & GRO000182 & 558 & 49.82 & 3.23 & 5.48 & 0.85 \\
\hline 17 Apr 2013 & GRO000937 & 526 & 54.12 & 3.72 & 5.36 & 0.84 \\
\hline 17 Apr 2013 & GRO000938 & 522 & 52.39 & 3.63 & 5.44 & 0.83 \\
\hline 17 Apr 2013 & GRO000939 & 506 & 53.43 & 3.81 & 5.39 & 0.84 \\
\hline 17 Apr 2013 & GRO000940 & 505 & 52.23 & 3.74 & 5.41 & 0.83 \\
\hline 18 Apr 2013 & GRO000941 & 497 & 48.68 & 3.54 & 5.51 & 0.83 \\
\hline 19 Apr 2013 & GRO000942 & 493 & 51.40 & 3.77 & 5.40 & 0.83 \\
\hline 20 Apr 2013 & GRO000183 & 492 & 49.91 & 3.66 & 5.27 & 0.96 \\
\hline 21 Apr 2013 & GRO000943 & 469 & 48.29 & 3.73 & 5.30 & 0.90 \\
\hline 22 Apr 2013 & GRO000945 & 477 & 51.46 & 3.90 & 5.31 & 0.85 \\
\hline 1 May 2013 & GRO000184 & & 79.94 & & 5.46 & 0.81 \\
\hline 17 May 2013 & GRO000946 & & 38.33 & & 5.70 & 0.84 \\
\hline 7 Jun 2013 & GRO000949 & & 25.20 & & 5.87 & 0.91 \\
\hline 22 Jun 2013 & GRO000947 & & 20.10 & & 5.92 & 0.95 \\
\hline 24 Jul 2013 & GRO000948 & & 15.37 & & 6.56 & 1.10 \\
\hline 24 Jul 2013 & GRO000948 & & 14.14 & & 6.71 & 1.05 \\
\hline 20 Sep 2013 & GRO000950 & & 9.26 & & 7.11 & 1.07 \\
\hline
\end{tabular}



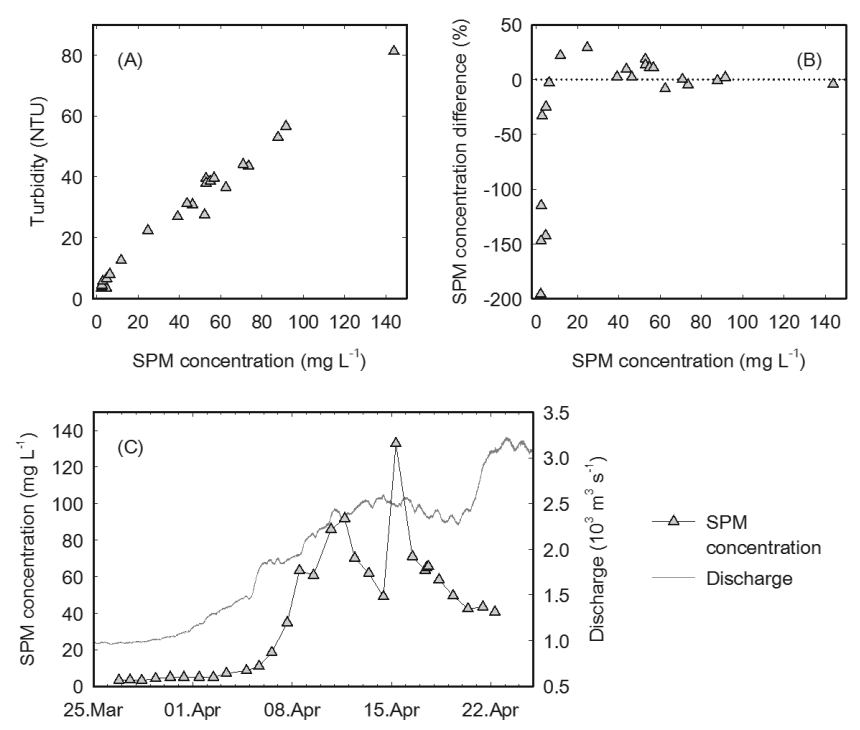

Figure 2. (a) Measured suspended particulate matter (SPM) concentration determined from the mass of sediment recovered from filtered water correlated strongly with turbidity measured with a nephelometer. (b) SPM concentration difference was calculated as the difference between the SPM concentration determined from the mass of sediment recovered from filtered water and that estimated from the linear correlation in panel (a). (c) Suspended sediment concentrations increased rapidly during the early freshet period.

ter grab samples (4-20L) were filtered with specially designed filtration units onto $90 \mathrm{~mm}$ polyethersulfone membrane filters (Millipore, pore size $0.22 \mu \mathrm{m}$ ). The resulting sediment was rinsed from filters with purified water (Millipore, $18.2 \mathrm{M} \Omega \mathrm{cm}^{-1}$ ), freeze dried, and weighed. As there is some loss of sediment in sample processing due to retention of a small amount of sediment within the filters, rather than use these measured concentrations directly, we have used the linear correlation between turbidity and filtered-mass sediment concentration (Fig. 2) to calculate SPM concentration based on nephelometer measurements. The SPM concentration values presented throughout the text are turbidity measurements converted to SPM concentration using this relationship.

\subsection{Organic matter analyses}

Fluorescent dissolved organic matter (FDOM) was measured in the field using a handheld probe (TurnerDesigns Cyclops-7 with DataBank). The probe was blank-calibrated with deionized water every 5 days and values are reported as blanked relative fluorescence units (RFUB). In situ FDOM was measured by lowering the probe from the dock at least $3 \mathrm{~m}$ below the river surface to eliminate possible interference from sunlight. Because changes in sediment concentration can significantly impact FDOM measurements (Saraceno et al., 2009), for each sample, a second FDOM measurement ("ex situ FDOM") was performed on filtered water (filtered with $0.2 \mu \mathrm{m}$ pore size membrane filters as described above) in a shaded vessel. Since fluorescence is temperature-sensitive, ex situ FDOM samples were filtered and analyzed as quickly as possible, with the FDOM measurement typically completed within $30 \mathrm{~min}$ of sample collection. The probe measurement frequency was $30 \mathrm{~s}$, and a minimum of 20 values were averaged to account for measurement variability.

Samples for the determination of DOC concentration were collected as $0.2 \mu \mathrm{m}$-filtered water (as described above) in precombusted $40 \mathrm{~mL}$ amber glass vials. Concentrated $\mathrm{HCl}$ was added immediately to achieve a $\mathrm{pH}$ of 2 and hinder biological activity. Samples were stored in the dark at $4{ }^{\circ} \mathrm{C}$ until analysis. DOC concentrations were determined by hightemperature catalytic oxidation on a Shimadzu TOC/TN-V instrument combined with a nitrogen chemiluminescence detection unit (TNM-1). Concentrations are reported as the mean of 3-5 replicate injections with a coefficient of variation $<2 \%$ (Mann et al., 2012).

Samples for the determination of DOM optical properties were collected in $20 \mathrm{~mL}$ polyethylene scintillation vials. Samples were stored at $4{ }^{\circ} \mathrm{C}$ in the dark until analysis. UVvisible absorbance spectra were measured at room temperature on a Shimadzu UV1800 dual-beam spectrophotometer using a $10 \mathrm{~mm}$ path length quartz cuvette. All samples were analyzed in triplicate and referenced to purified laboratory water (MilliQ, $18.2 \mathrm{M} \Omega \mathrm{cm}^{-1}$; Mann et al., 2012). Naperian absorption coefficients $(a(\lambda))$ were calculated at integer wavelengths between $200-800 \mathrm{~nm}$ from absorbance as follows:

$\alpha(\lambda)=2.303 \times A(\lambda) / l$,

where $A(\lambda)$ is the measured absorbance and $l$ is the cell path length in meters (Del Vecchio and Blough, 2002). Absorbance at specific wavelengths can be diagnostic of certain DOM properties (e.g., Spencer et al., 2012). Normalizing DOC concentrations to wavelength-specific absorbance (e.g., $\mathrm{SUVA}_{254}=$ absorbance at $254 \mathrm{~nm}$ divided by DOC concentration in $\mathrm{mg} \mathrm{L}^{-1}$ ) allows the chromophoric character of DOM in different settings to be compared, and the value of SUVA $_{254}$ has been previously shown to be positively correlated with bulk aromaticity (Weishaar et al., 2003). The absorbance ratio $\left(a_{250} / a_{365}\right)$ represents the ratio of absorbance coefficients at two wavelengths ( 250 and $365 \mathrm{~nm}$ ), and has previously been shown to be negatively correlated with molecular weight and aromaticity of DOM (Peuravuori and Pihlaja, 1997). The slope ratio $\left(S_{\mathrm{R}}\right)$ represents the ratio of the slopes of the absorbance-wavelength curve over two wavelength ranges (275-295 and 350-400 nm) and is also negatively correlated with DOM molecular weight and aromaticity, as well as relative vascular plant content (cf. Spencer et al. (2012) and sources therein). The use of multiple optical proxies provides support from multiple metrics for interpretations of the data.

For bulk carbon and nitrogen content and stable isotope analysis, suspended sediment samples were weighed in trip- 
licate into combusted silver capsules. Samples were then exposed to concentrated $\mathrm{HCl}$ vapor under partial vacuum at $65^{\circ} \mathrm{C}$ for 3 days to remove carbonate. Organic carbon and nitrogen concentrations $\% \mathrm{OC}$ and $\% \mathrm{~N}$, weight percent of total sediment mass) and stable isotope values $\left(\delta^{13} \mathrm{C}\right.$ and $\delta^{15} \mathrm{~N}$ ) were measured on an Elemental Analyzer (Carlo Erba 1107) coupled via a Finnigan-MAT Conflo II open split interface to a Delta ${ }^{\text {Plus }}$ stable isotope ratio mass spectrometer for measurement of ${ }^{13} \mathrm{C} /{ }^{12} \mathrm{C}$ (referenced to Vienna Pee Dee Belemnite) and ${ }^{15} \mathrm{~N} /{ }^{14} \mathrm{~N}$ (referenced to $\mathrm{N}_{2}$ air; IAEA, 1995). Sample $\% \mathrm{OC}, \% \mathrm{~N}, \delta^{13} \mathrm{C}$, and $\delta^{15} \mathrm{~N}$ values were determined from standard reference materials NBS-19 limestone (Coplen et al., 2006), IAEA-N-1 ammonium sulfate (Böhlke et al., 1993), USGS-40 glutamic acid (Qi et al., 2003), and an internal glycine standard. Analytical accuracy and precision of these measurements ( 1 s.d.) are $0.1 \mathrm{wt}$. \% for $\mathrm{C}$ and $\mathrm{N}$ abundance, $0.3 \%$ or for $\delta^{13} \mathrm{C}$, and $0.4 \%$ o for $\delta^{15} \mathrm{~N}$.

\subsection{Mercury analyses}

Water samples for $\mathrm{Hg}$ concentrations were collected in precleaned $250 \mathrm{~mL}$ glass bottles, that were double-bagged and handled using "clean hands-dirty hands" approaches (Patterson and Settle, 1976), and stored in the dark after collection. Bottles were prepared following procedures outlined in Hammerschmidt et al. (2011); all materials were prepared in an ISO 5 cleanroom. Following established procedures (US EPA, 2002), samples were preserved with $\mathrm{BrCl}$ (final concentration of $0.5 \% \mathrm{w} / \mathrm{w}$ ) within 30 days of collection, then stored in the dark at $4{ }^{\circ} \mathrm{C}$ until analysis. Total dissolved $\mathrm{Hg}$ (TDHg) concentration represents water samples filtered to $0.2 \mu \mathrm{m}$ (as described above), while total $\mathrm{Hg}$ ( $\mathrm{THg}$ ) concentration represents unfiltered water samples. In a clean laboratory, samples were oxidized on the day before analysis with $100 \mu \mathrm{L}$ saturated $\mathrm{BrCl}$ solution to convert all $\mathrm{Hg}$ species to $\mathrm{Hg}^{2+}$, then reduced with $100 \mu \mathrm{L}$ each $\mathrm{NH}_{2} \mathrm{OH} \cdot \mathrm{HCl}$ and $\mathrm{SnCl}_{2}$ immediately before analysis to convert all species to elemental gaseous $\mathrm{Hg}^{0}$. Mercury concentrations were determined using a purge and trap/cold vapor atomic fluorescence spectrometry total mercury analyzer (Tekran 2600). A MilliQ water $\left(18.2 \mathrm{M} \Omega \mathrm{cm}^{-1}\right)$ blank was analyzed at the beginning of each day of analysis to ensure that background signal was sufficiently low ( $\sim 0.5 \mathrm{pmol})$. A standard curve was generated from analyses of varying quantities of aqueous standard (NIST SRM-3133), which was checked against a vapor $\mathrm{Hg}^{0}$ saturated air standard held at $15^{\circ} \mathrm{C}$ (Tekran 2505) and introduced to the detection system using a gas-tight syringe. Samples were analyzed at least three times until standard deviations were $<10 \%$ of the measured value, or until sample material was exhausted.

Total $\mathrm{Hg}$ concentration in suspended particulate matter (SPM THg) was analyzed on material recovered from membrane filters. SPM samples were analyzed on a Milestone Direct Mercury Analyzer (DMA-80) following established methods (US EPA, 2007). Concentrations were calibrated us- ing standards MESS-3 and PACS-2 (marine sediments; National Research Council Canada) and IAEA-SL-1 (lake sediment; International Atomic Energy Agency). Samples were analyzed in pre-combusted $\left(500^{\circ} \mathrm{C}, 1 \mathrm{~h}\right)$ nickel boats.

\section{Results}

\subsection{Early freshet water chemistry trends}

During the period 26 March-22 April 2013, hereafter referred to as the "early freshet," discharge (at Hope) increased from 950 to $3000 \mathrm{~m}^{3} \mathrm{~s}^{-1}$. SPM concentrations were very low (3-9 $\mathrm{mg} \mathrm{L}^{-1}$ ) for the first $\sim 10$ days, then increased rapidly to higher, but variable values (40-150 $\mathrm{mg} \mathrm{L}^{-1}$; Fig. $2 \mathrm{c}$ ).

Nutrient concentrations varied significantly during the early freshet period $\left(\mathrm{NO}_{3}+\mathrm{NO}_{2}: 4-19 \mu \mathrm{mol} \mathrm{L}{ }^{-1}\right.$, $\mathrm{PO}_{4}: \quad 0.2-0.7 \mu \mathrm{mol} \mathrm{L}-1 ; \quad \mathrm{NH}_{4}: \quad 0.4-2.3 \mu \mathrm{mol} \mathrm{L}-1 ; \mathrm{SiO}_{2}$ : $83-113 \mu \mathrm{mol} \mathrm{L}^{-1}$; Fig. S2). Nitrate/nitrite and $\mathrm{NH}_{4}$ concentrations showed slight decreasing trends, continuing the decline from peak winter values that is typical of the seasonal cycle in the Fraser River and other temperate to high-latitude fluvial systems (Cameron, 1996; Voss et al., 2014; Whitfield and Schreier, 1981). Phosphate and dissolved $\mathrm{SiO}_{2}$ concentrations did not show clear trends. Nutrient concentrations during the early freshet exhibited a substantial portion of the total annual variation. Such large day-to-day variability was not anticipated based on lower frequency (i.e., once to twice monthly) time series sampling presented by Voss et al. (2014).

Concentrations of some major dissolved species $(\mathrm{Na}, \mathrm{Cl}$, $\mathrm{SO}_{4}$ ) decreased as discharge increased during the early freshet (Fig. S3). Others decreased for the first 2 weeks, then increased $(\mathrm{Mg}, \mathrm{K})$ or remained relatively stable $(\mathrm{Ca})$. Those elements which exhibited a systematic decrease in concentration throughout the early freshet are more significantly influenced by sea salt aerosols in precipitation relative to chemical weathering of rocks than those characterized by more variable behavior. All major species except $\mathrm{SiO}_{2}$ (which is also a nutrient) showed significant linear correlations $(p<0.01$, $95 \%$ confidence interval) with conductivity (a proxy for total dissolved solids).

The stable isotope composition of water $\left(\delta \mathrm{D}, \delta^{18} \mathrm{O}\right)$ showed a steady shift to lighter compositions over the 2013 early freshet (Fig. S4). The change $(>15 \%$ in $\delta \mathrm{D}$ over 27 days) is large and rapid in the context of the total annual variability in this parameter ( $\sim 40 \%$ o in $\delta \mathrm{D}$; Voss et al., 2014$)$. Deuterium excess $\left(\delta \mathrm{D}-8 \times \delta^{18} \mathrm{O}\right.$; values not shown $) \mathrm{de}-$ creased during this period from $\sim 8.4$ to $\sim 4.7 \%$ o.

Early freshet changes in DOM concentration were monitored in the field by proxy from FDOM probe measurements. Filtered FDOM values (539-1856 RFUB) correlated strongly with measured DOC concentrations, with an apparent approach towards a plateau in FDOM $(\sim 1800$ RFUB $)$ at high DOC ( $>500 \mu \mathrm{mol} \mathrm{L}{ }^{-1}$; Fig. S5a), likely due to light 

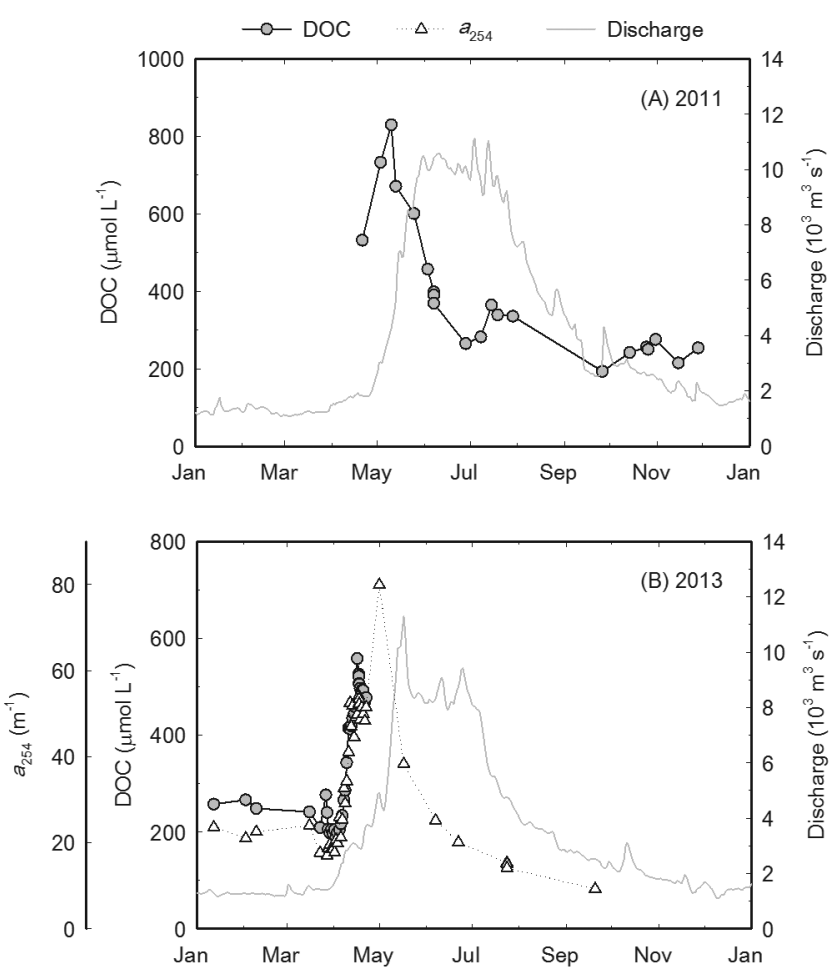

Figure 3. Concentrations of dissolved organic carbon (DOC) peak during the early stages of the spring freshet and decrease over the course of the summer.

attenuation from increasing chromophoric DOM (Downing et al., 2012; Pereira et al., 2014). The suspended sediment concentration was found to account for most of the difference between in situ and filtered ex situ FDOM measurements (Fig. S5b).

\subsection{Seasonal changes in $\mathrm{OC}$ concentration and $\mathrm{OM}$ composition}

In both 2011 and 2013, DOC concentrations rose rapidly during the early freshet period from fall/winter levels of $\sim 200 \mu \mathrm{mol} \mathrm{L}^{-1}$ to a peak of $700-900 \mu \mathrm{mol} \mathrm{L}^{-1}$ (Fig. 3). This "pulse" of DOC occurs at the very onset of the rise in discharge, with peak DOC concentrations achieved when discharge had only reached $40 \%$ of its maximum. DOC concentration is positively correlated with wavelength-specific absorption coefficients (Fig. 4).

Optical properties of DOM reveal changes in the composition of the DOM pool during the early freshet period, as well as at other times of the year (Fig. 5). During the early freshet of the Fraser River in 2013, values of $a_{250} / a_{365}$ and $S_{\mathrm{R}}$ decrease, while $\mathrm{SUVA}_{254}$ increases. These early freshet changes are part of a larger seasonal cycle, shown in Fig. 5 for $a_{250} / a_{365}$ and $S_{\mathrm{R}}$. While the values of these parameters decrease during the early freshet DOC pulse, they gradually rise throughout the summer, peaking in early fall. In winter, values drop again before rising rather abruptly prior to the

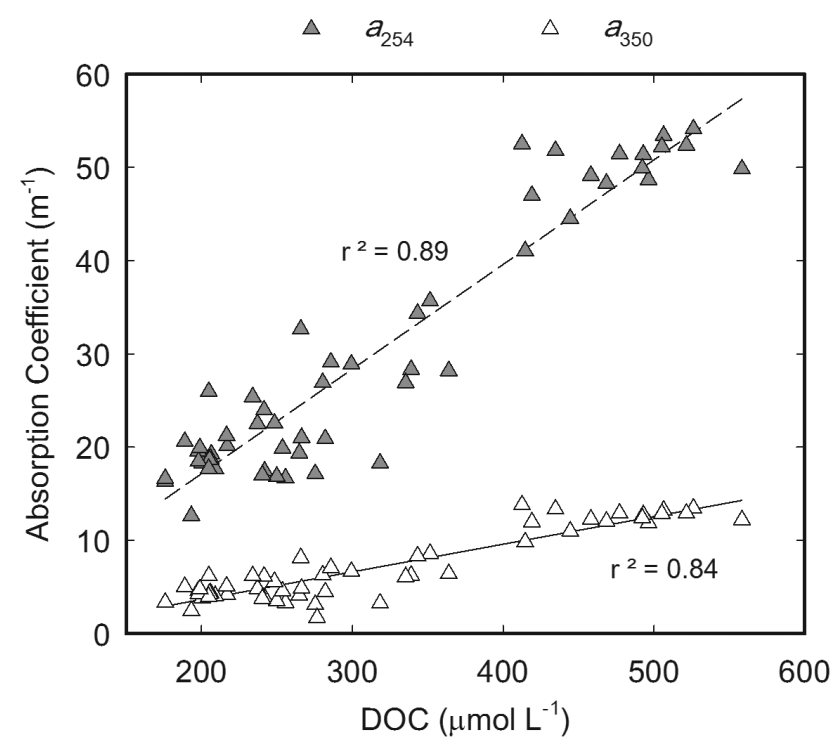

Figure 4. DOC concentration is strongly correlated with absorption coefficients (shown here at 254 and $350 \mathrm{~nm}$ ).

early freshet. For the $\sim 2$-year record of these DOM optical properties, both $S_{\mathrm{R}}$ and $a_{250} / a_{365}$ show a consistent twiceyearly cycle between higher values in fall and early spring and lower values in winter and during the early freshet (and the reversed trends for $\mathrm{SUVA}_{254}$ ), exhibiting a hysteresis cycle with discharge similar to DOC concentration.

In addition to DOC concentration, the POC concentration and particulate organic matter (POM) composition change rapidly during the early freshet (Fig. 6). Although the OC content of suspended sediments decreases during this time (from 4.5 to $0.8 \%$ ), the increase in SPM concentration is so large that the POC concentration rises by an order of magnitude (from 9 to $89 \mu \mathrm{mol} \mathrm{L}^{-1}$ ). The relative change in POC concentration is greater than that of DOC concentration, as the DOC:POC ratio decreases from a value of 30 on 26 March to a minimum of 4.6 on 8 April, followed by values of $\sim 10$ over the following 2 weeks. The $\mathrm{C}: \mathrm{N}$ composition of POM also changes, with values before 6 April varying between 8.5 and 9.9 (excepting the values of 10.5 on 27 March and 10.3 on $31 \mathrm{March}$ ), and then rising to values between $10-11$ for the remainder of the sampling period. The $\delta^{13} \mathrm{C}$ of POC also varied ( -27.7 to $-26.1 \%$ ); however, no clear trends are apparent.

\subsection{Early freshet changes in mercury concentration}

Total dissolved $\mathrm{Hg}$ (TDHg) concentrations varied between 5.9 and $15.2 \mathrm{pmol} \mathrm{L}^{-1}$, with no distinct temporal trend during the early freshet period (Fig. 7). In contrast, unfiltered $\mathrm{THg}$ concentrations increased significantly in a matter of days during this period, with concentrations before 7 April of $\sim 15 \mathrm{pmol} \mathrm{L}^{-1}$ and those on and after this date of $\sim 50 \mathrm{pmol} \mathrm{L}^{-1}$. The portion of the total $\mathrm{Hg}$ load composed of 


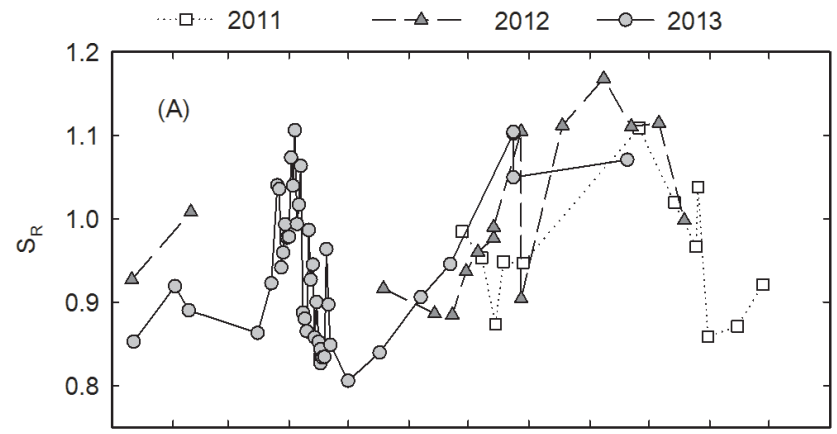

Jan Feb Mar Apr May Jun Jul Aug Sep Oct Nov Dec Jan

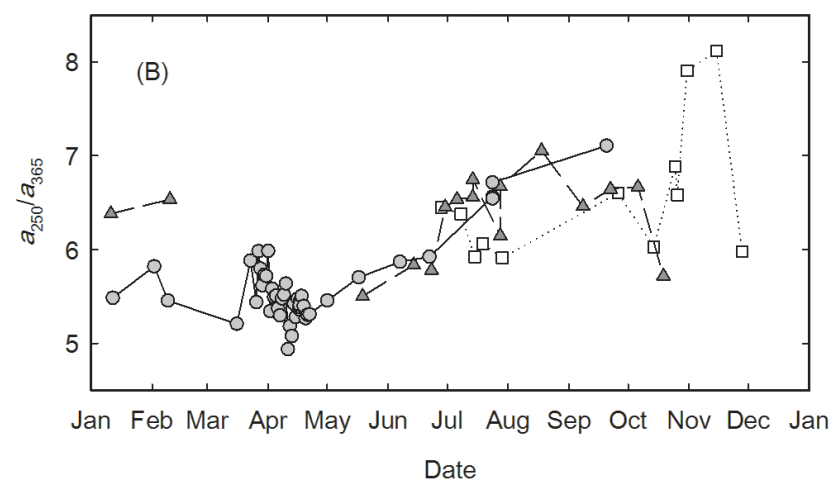

Figure 5. (a) Spectral slope ratio $\left(S_{\mathrm{R}}\right)$ and (b) absorbance ratio $\left(a_{250} / a_{365}\right)$ show rapid changes in DOM composition during the early freshet DOC pulse. A more gradual return to pre-freshet composition follows throughout the summer. A second cycle occurs in late winter.

dissolved $\mathrm{Hg}$ correspondingly decreased from $\sim 75 \%$ before 7 April to $<25 \%$ afterwards.

Results of suspended sediment $\mathrm{Hg}$ concentrations are presented with consideration of analytical detection limits. Empty combusted nickel boats were analyzed to determine the analytical blank of the sediment $\mathrm{Hg}$ analysis: $0.37 \pm 0.20 \mathrm{ng} \mathrm{Hg}$ (avg. $\pm 1 \mathrm{SD}$ ). The total amount of $\mathrm{Hg}$ analyzed in suspended samples ranged from 1.2-4.9 ng. The very low amounts of $\mathrm{Hg}$ reported here are above the detection limit $(3 \times$ standard deviation of blank $=0.6 \mathrm{ng})$, but in two of six samples were not quantifiable $(10 \times$ standard deviation of blank $=2.0 \mathrm{ng}$ ). This limitation does not, however, affect the conclusions drawn from the data. Concentrations of $\mathrm{Hg}$ in SPM were relatively constant, varying between $0.43-$ $0.46 \mathrm{pmol} \mathrm{mg}^{-1}$.

\section{Discussion}

\subsection{Rapid geochemical changes in the early freshet}

The geochemical data presented here highlight the importance of the very early portion of the spring freshet to biogeochemical dynamics in the Fraser River. While discharge and basic water properties (temperature, $\mathrm{DO}, \mathrm{pH}$, conductivity, and major element concentrations) record only modest changes during this interval, the initial melting of snowpack is reflected in a suite of geochemical shifts, including water $\delta \mathrm{D}$ and $\delta^{18} \mathrm{O}$ composition, SPM concentration, and OM concentration and composition.

The sudden change in water sources from different portions of the basin is demonstrated by the rapid decrease in $\delta \mathrm{D}$ and $\delta^{18} \mathrm{O}$ values. As runoff from headwater areas and snowmelt with signatures more depleted in heavy isotopes begins to contribute a greater portion of the total discharge, the lower Fraser main stem quickly records this transition at the whole basin-scale. Quantification of the proportional contributions of various water sources (particular snowpacks and tributaries) based on the observed changes in stable isotope composition is complicated due to insufficient knowledge of source water compositions. The isotope composition of precipitation in the Fraser basin is poorly characterized and the $\delta \mathrm{D}$ and $\delta^{18} \mathrm{O}$ values of individual tributaries are highly variable across the year (Voss et al., 2014). Furthermore, the isotope composition of snow and ice likely varies with elevation and water vapor source, causing the composition of the snow within a single tributary basin to vary as seasonal melting progresses. The magnitude of the change in isotope composition of the Fraser main stem, however, is sufficiently large that the transition to greater headwater and snowmelt influence during the early freshet is unequivocal.

Assuming that the deuterium excess of Pacific Ocean source moisture does not change seasonally, the shift towards lower deuterium excess during the early freshet indicates a change in the continental transport pathways and/or evaporation processes affecting spring vs. winter precipitation in the Fraser basin (Froehlich et al., 2008; Riche et al., 2014). In the absence of spatially resolved precipitation isotopic data, we can surmise that the apparently lower deuterium excess of winter snowpack relative to spring rainfall is due to more evaporative recycling over land en route to the site of precipitation for the latter than for winter snowfall. This proposition should be further tested with time series observations of stable isotopes in precipitation, snow and ice, and small streams across the basin.

A pronounced geochemical shift is recorded by the change in concentration of DOC. DOM dynamics are driven by a combination of hydrological and biological processes. When discharge is low at base flow levels, hydrologic flow paths through soil are relatively deep and slow, drawing modest amounts of DOM from deeper soil layers (Townsend-Small et al., 2011). This DOM is likely older and more degraded from its parent plant source material as a result of preferential remineralization of younger carbon sources by soil microbiota (Gangloff et al., 2014), although a portion of soil DOM may also derive from soil biota. Preferential sorption of DOM to soil particles may also influence soil DOC concentration and DOM composition, enhancing DOM removal during base flow periods. As discharge and overland flow 

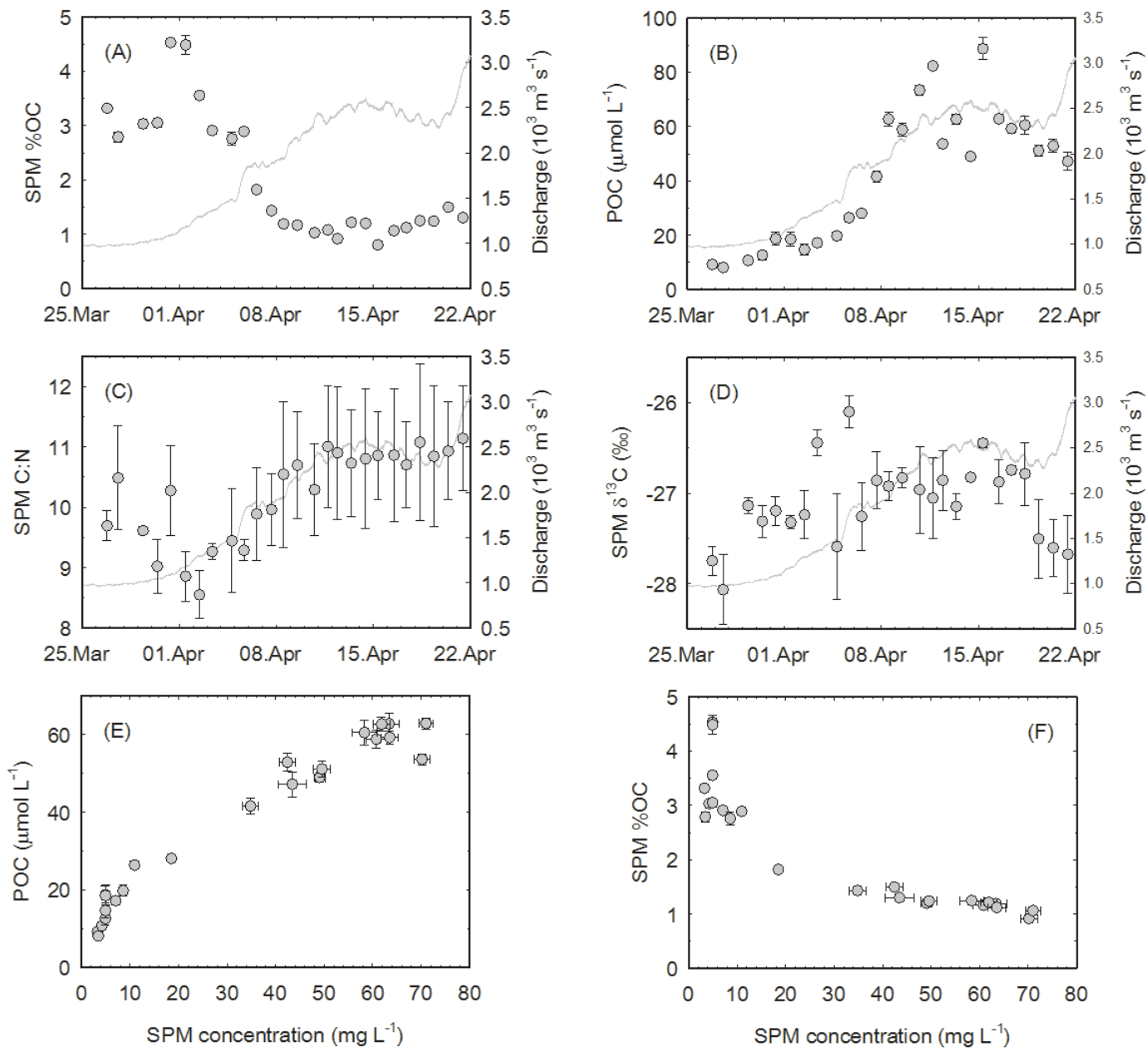

Figure 6. The abundance and composition of POC shifted during the early freshet period towards (a) relatively lower \%OC, (b) higher POC concentration, and (c) higher $\mathrm{C}: \mathrm{N}$. (d) No distinct temporal trend is evident in $\delta^{13} \mathrm{C}$. (e) POC concentration and (f) SPM OC content are tightly coupled with SPM concentration. Error bars represent 1 s.d. of triplicate measurements. Discharge is shown as gray lines in (a)-(d).

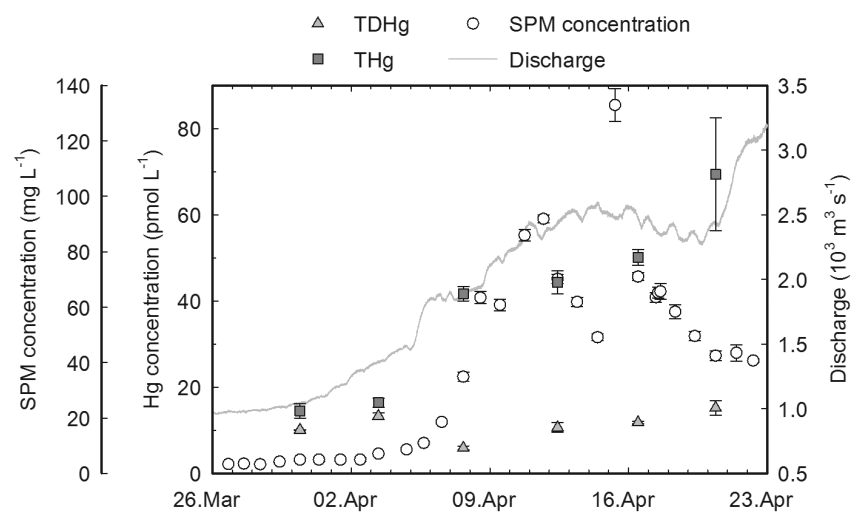

Figure 7. Total mercury concentrations in filtered (TDHg) and unfiltered (THg) water samples during the 2013 early freshet period. Error bars represent 1 s.d. of repeated measurements. increase and soils become inundated across the basin, hydrologic flow paths draw DOM from greater distances from stream channels and shallower soil horizons. Despite potential dilution from increased discharge, this DOM is likely more concentrated, and exported to stream channels more quickly than base flow DOM (Michalzik et al., 2001, 2003), leading to a pulse of DOM into streams.

The average total DOC flux of the Fraser River can be estimated from our 3-year record, as well as from the 16-year record from Environment Canada in the city of Hope. Hope is $\sim 100 \mathrm{~km}$ upstream of the sampling site used in our study, and notably excludes a large portion of the agricultural Fraser Valley and a large, DOC-poor Coast Range tributary, the Harrison River. Despite these differences, the estimates of total Fraser River DOC flux based on these two records (Table 3 ) agree within their uncertainties $\left(2.8 \pm 1.0 \times 10^{10} \mathrm{~mol} \mathrm{Ca}^{-1}\right.$ for the record in this study, $2.7 \pm 0.4 \times 10^{10} \mathrm{~mol} \mathrm{C} \mathrm{a}^{-1}$ for the Environment Canada record), with the longer Environment Canada record showing smaller uncertainty, as expected. The 
Table 3. Discharge-weighted fluxes and concentrations of DOC in the Fraser River. Environment Canada data were accessed online at http://aquatic.pyr.ec.gc.ca. Sampling for both Environment Canada and this study was performed at approximately twice monthly frequency, with the exception of our 2013 freshet sampling, for which sampling was daily.

\begin{tabular}{lll}
\hline & $\begin{array}{l}\text { Environment Canada record } \\
\text { at Hope (1998-2013) }\end{array}$ & This study (2011-2013) \\
\hline DOC flux $\left(\mathrm{mol} \mathrm{C} \mathrm{a}^{-1}\right)$ & $2.7 \pm 0.4 \times 10^{10}$ & $2.8 \pm 1.0 \times 10^{10}$ \\
DOC yield $\left(\mathrm{mol} \mathrm{k} \mathrm{km}^{-2} \mathrm{a}^{-1}\right)$ & $1.2 \times 10^{5}$ & $1.2 \times 10^{5}$ \\
Discharge-weighted average DOC concentration $\left(\mu \mathrm{mol} \mathrm{L}^{-1}\right)$ & $277 \pm 14$ & $270 \pm 71$ \\
\hline
\end{tabular}

DOC yield of the Fraser River $\left(1.2 \times 10^{5} \mathrm{~mol} \mathrm{C} \mathrm{km}^{-2} \mathrm{a}^{-1}\right)$ is significantly greater than that of the nearby Columbia River $\left(0.5 \times 10^{5} \mathrm{~mol} \mathrm{k} \mathrm{km}^{-2} \mathrm{a}^{-1}\right)$, and comparable to that of the Yukon River to the north $\left(1.4 \times 10^{5} \mathrm{~mol} \mathrm{C} \mathrm{km}^{-2} \mathrm{a}^{-1}\right.$; Spencer et al., 2013). Absent quantitative estimates of headwater fluxes of DOC to the main stem of each of these rivers, these differences in DOC yields suggest that DOC mobilized in the Fraser River is retained more effectively during downstream transport than in the Columbia River, while DOC in the Yukon River is transported roughly as efficiently as in the Fraser. The extensive reservoir impoundment of the Columbia River may be an important factor in the apparently greater loss of terrestrial DOC from this system, while lower terrestrial productivity in the vast arid portions of the Columbia basin likely also generate smaller inputs of soil DOC than in the forested Fraser basin. The more natural hydrologic regime of the Yukon River, and land cover composed largely of forests and wetlands, likely contribute to its similar DOC yield compared to that of the Fraser River.

\subsection{Annual cycles of DOM composition and sources}

Considering the full annual records of DOC concentration and DOM composition, it is evident that DOM composition varies at times outside the spring freshet. Throughout the summer, as main stem DOC concentration decreases toward base flow levels, the DOM optical properties gradually return to values similar to those of pre-freshet DOM (higher $a_{250} / a_{365}$ and $S_{\mathrm{R}}$, lower $\left.\mathrm{SUVA}_{254}\right)$. In the late fall, while DOM concentrations remain low, optical properties once again shift to freshet-like compositions (lower $a_{250} / a_{365}$ and $S_{\mathrm{R}}$, higher $\mathrm{SUVA}_{254}$ ), and then return to pre-freshet composition in late winter/early spring, just before the early freshet DOC pulse. Although daily records of DOC concentration in the Fraser River are not available for the fall period, the Environment Canada record (beginning in 1998, approximately twice monthly sampling) indicates that a secondary peak in DOC concentration $\left(300-500 \mu \mathrm{mol} \mathrm{L}^{-1}\right)$ often occurs between September and December.

The twice-annual cycle in DOM composition appears to be driven by hydrologic changes. The early freshet shift represents more rapid export of shallow soil DOM driven primarily by melting snowpack across the basin. The compositional change in the fall is likely driven by a similar flushing of shallow soil DOM derived from biomass accumulated over the growth season and mobilized by large rain events, as has been observed in the Yukon River (Wickland et al., 2012), as well as in non-snowmelt-driven systems such as the Mississippi River (Bianchi et al., 2013). The Fraser basin, particularly in areas east of the Coast Range, generally receives very little precipitation in the late summer months, which allows litter from fresh vegetation to accumulate and DOM export to revert to slower, deeper flow paths (Oswald and Branfireun, 2014). Warmer temperatures in late summer relative to spring may also promote more rapid microbial degradation of soil DOM, thus diminishing the potential amount of DOM that can enter streams. In the winter, precipitation in much of the basin falls primarily as snow, which limits surface runoff. Fall precipitation (rain), however, is capable of flushing shallow soil DOM into streams. The more freshetlike composition of this fall DOM suggests that it has a similar soil residence time and limited degradation history.

The smaller quantity of DOC mobilized by fall soil flushing compared to that of the spring freshet (evident in the smaller fall pulses of DOC exhibited by the long-term Environment Canada DOC record) is likely due to incomplete recovery of the soil DOC pool to its pre-freshet size, in addition to the fact that the amount of runoff generated by fall rain storms is much less than that from spring snowmelt. The relative magnitude and composition of fall DOC pulses may also be affected by spatial differences in vegetation types (e.g., between coniferous forests which dominate the mountainous portions of the basin and the bunchgrass and dryland vegetation covering significant portions of the interior basin), which also likely exhibit variations in the timing of growing seasons. Growing season varies significantly across the Fraser basin, from $>170$ days per year in the Fraser Valley area to $<100$ days in the Coast Range and parts of the Rocky Mountains (Agriculture and Agri-Food Canada, 2014). Consequently, this relatively small input of compositionally distinct DOM to the base flow DOM load of the Fraser causes a change in DOM optical properties of a similar magnitude to that seen during the early freshet. It should be noted, however, that optical parameters are not necessarily a linear function of the relative quantity of the functional components responsible for them (Stedmon and Markager, 2003; Yang and Hur, 2014). The spatial extent and magnitude of 
fall rain events is also highly variable from year-to-year and across different tributary catchments; hence the fall and winter DOM composition changes are likely to be more variable than those during the freshet.

The fact that DOC concentrations peak and begin to fall before discharge reaches its freshet zenith indicates that this hydrologic flushing of DOM is limited by the size of the shallow soil DOM pool, and/or by the differences in snowmelt timing across the basin. Disentangling these effects would require extensive knowledge of seasonal changes in DOM flux and composition from individual tributary basins. If the spring freshet effectively flushes the shallow soil DOM pool across the basin, this implies a decoupling from the deep soil DOM pool, as negligible shallow DOM is able to persist during high flow conditions, and transfer to deeper soil layers only occurs between late summer and the following spring. A stronger understanding of the nature of interaction between shallow and deep soil DOM pools would further inform the results of this study. An investigation of seasonal changes in soil DOM properties (e.g., concentration, optical properties, biolability, ${ }^{14} \mathrm{C}$ age) with depth could build on the results presented here by identifying whether hydrologic flushing imparts a "fresh" DOM signature on deep soil DOM and how long such a signature persists.

The brief rise in $S_{\mathrm{R}}$ at the beginning of the freshet DOC pulse may indicate an initial release of highly soluble and less aromatic, lower molecular weight or non-chromophoric DOM that is quickly overwhelmed by more aromatic, higher molecular weight DOM for the remainder of the pulse as $S_{\mathrm{R}}$ drops (Ward et al., 2012). Such an initial shift is less clear in the $a_{250} / a_{365}$ and $\mathrm{SUVA}_{254}$ records at the onset of the 2013 freshet, thus an initial shift in DOM composition during the freshet DOC pulse requires further investigation. In addition, the magnitude of anthropogenic contributions to the dissolved and particulate OC load of the Fraser basin could potentially be investigated through measurement of tracers such as mammalian fecal markers (e.g., coprostanol) or phenolic flavor compounds (e.g., Writer et al., 1995; Keil et al., 2011).

The average depth of the shallow soil horizon responsible for the freshet pulse of DOC can be estimated from the volume of water above base flow discharged during this pulse. In 2013, the freshet DOC pulse - from the point when DOC concentration began to rise rapidly until it returned to nearly pre-freshet values - lasted approximately from 5 April to 7 June. The cumulative discharge of the Fraser River during this time was $33 \mathrm{~km}^{3}$, or $28 \mathrm{~km}^{3}$ subtracting a constant base flow of $950 \mathrm{~m}^{3} \mathrm{~s}^{-1}$. If this volume of water constitutes the shallow soil end member, we estimate that the maximum shallow soil DOC concentration during this time period is $900-950 \mu \mathrm{mol} \mathrm{L}^{-1}$, assuming a base flow DOC concentration of $100-200 \mu \mathrm{mol} \mathrm{L}^{-1}$. Given an average forest soil porosity of $\sim 0.43$ in British Columbia (Zhao et al., 2008), the actual soil volume represented by $28 \mathrm{~km}^{3}$ of water is $\sim 65 \mathrm{~km}^{3}$. If this volume is distributed equally across the entire basin $\left(228776 \mathrm{~km}^{2}\right)$, it corresponds to a soil depth of $\sim 28 \mathrm{~cm}$. Given that soil porosity varies considerably across the basin (as low as 0.15 in highly compacted fine-grained and agricultural soils, and as high as 0.70 in coarse-grained soils), depths of ca. $20-80 \mathrm{~cm}$ could be flushed in different localities. This estimate represents a basin-wide average soil depth; it is likely that the majority of the DOC pulse derives from soil water in the top centimeters with DOM concentrations much higher than that observed in the river, due to dilution by low-DOM snow melt, low-DOM soil water from deeper layers, and respiration between the point of mobilization into the stream and the sampling location. Total soil depth (above bedrock) is also highly variable across the basin, ranging from $<0.5 \mathrm{~m}$ in rapidly eroding mountainous areas to $>3 \mathrm{~m}$ in flatter areas that have accumulated significant glaciofluvial sediments (Valentine et al., 1978; Vold, 1979). An estimate of a surface horizon of $0.2-0.8 \mathrm{~m}$ flushed during the freshet DOC pulse is therefore a reasonable firstorder approximation of the maximum spatial extent of this event.

In addition to hydrologic and soil microbial controls on DOM dynamics, in-stream and lacustrine biological activity may play a role in the observed changes in DOC concentration and DOM composition. Throughout the spring freshet and summer, nutrient concentrations in the Fraser main stem also decrease. Similar to DOC, this trend is likely due in part to changes in the sources of nutrients from soil flushing. However, nutrients are also consumed by autotrophic activity in some portions of the basin, particularly in tributary basins containing lakes. In these basins, such as the Thompson, Nechako, and Quesnel rivers, lakes function as suspended sediment filters, allowing sunlight to penetrate more deeply. Such basins are likely especially depleted in nutrients in spring and summer, and may also contribute some DOM derived from autotrophic production. This DOM would have optical properties reflecting a less aromatic, lower molecular weight composition (Rochelle-Newall and Fisher, 2002). Aquatic autotrophic and heterotrophic DOM input is likely strongest during summer, when water temperatures are higher and discharge and river sediment concentrations are lower than during the peak freshet. More detailed data on seasonal and spatial variability in DOC concentration and DOM composition within these tributary basins would be needed to better constrain this potential source of DOM to the main stem Fraser.

We used the concentrations and optical properties of DOC to estimate the contributions of "shallow" vs. "deep" soilderived DOC to the total DOC load of the Fraser River (Fig. 8). Assuming that the maximum and minimum values of the optical properties observed in our time series represent these hypothetical end-members, we determined the proportion of deep and shallow soil-derived DOC for each point in the time series, and generated discharge-weighted average values using LoadEst (Table 4). As derived optical properties such as $a_{250} / a_{350}$ and $S_{\mathrm{R}}$ may not vary linearly as a func- 

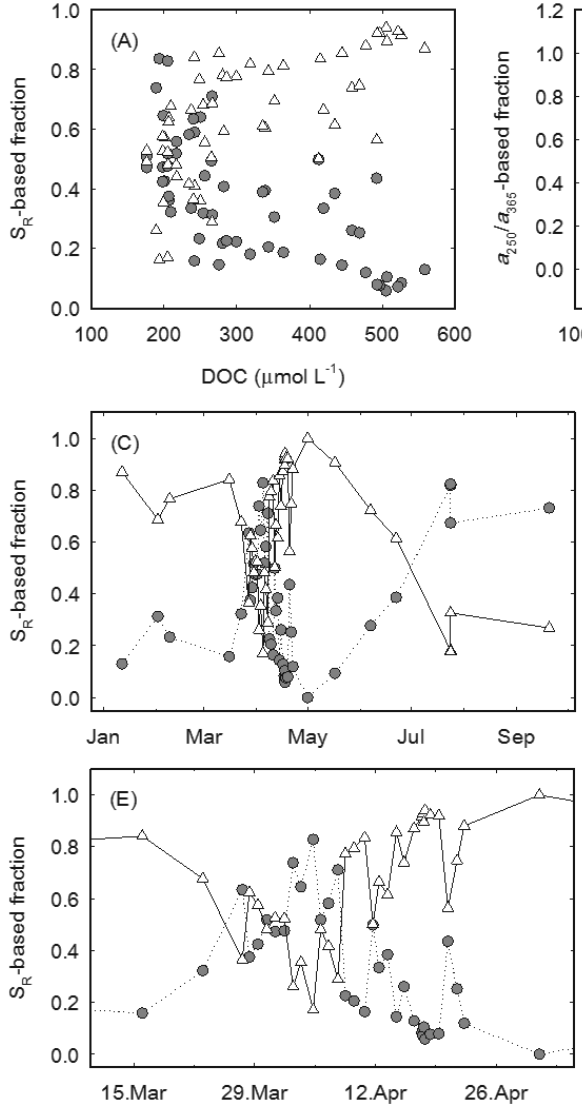
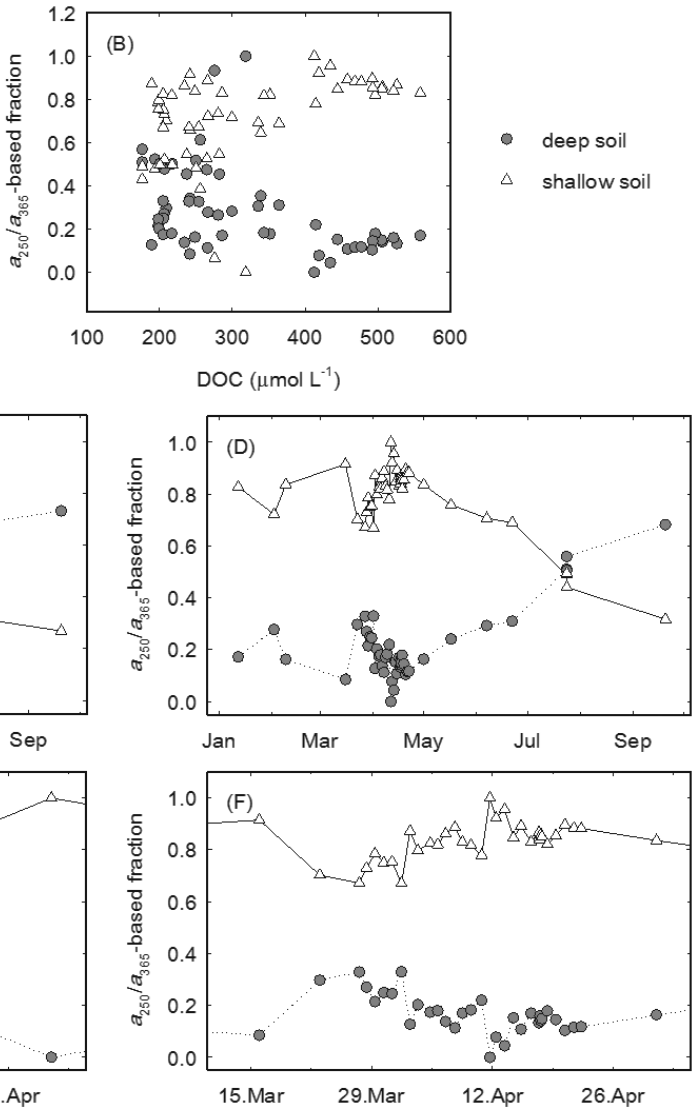

Figure 8. The contributions of deep and shallow soil DOC to total Fraser DOC were estimated based on the observed maximum and minimum values of DOC optical properties (spectral slope ratio, $S_{\mathrm{R}}$, and absorbance ratio, $a_{250} / a_{365}$ ). These fractions are related to the DOC concentration (a and b), and change throughout the year (c and d, shown here for 2013; $\mathbf{e}$ and $\mathbf{f}$ detail the 2013 early freshet period).

tion of end-member inputs (Yang and Hur, 2014; Stedmon and Markager, 2003), the results of this mixing model are intended to show seasonal trends and differences, while the absolute fractions of end-member contributions are necessarily approximate. With this in mind, both $S_{\mathrm{R}}$ and $a_{250} / a_{365}$ indicate that, on average, shallow soil-derived DOC constitutes $\sim 60 \%$ of the total DOC flux. The estimated fractions of total DOC derived from deep and shallow soils varies nonlinearly with DOC concentration (Fig. 8). This may reflect the observation from the time series record that DOM optical properties can change on the basin scale not only during the spring freshet, but also in response to relatively small hydrologic changes while the total DOC load is less variable.

The role of the Fraser River in transferring terrestrial OC to the coastal ocean can be assessed by comparing the fluxes of DOC and POC with total carbon fixation by land plants. The global compilation of riverine OC fluxes of Ludwig et al. (1996) reports net primary productivity (NPP) in the Fraser basin of $585 \mathrm{~g} \mathrm{C} \mathrm{m}^{-2} \mathrm{a}^{-1}$ (however no OC fluxes are reported), corresponding to total terrestrial carbon fixation in the basin of $\sim 4.0 \times 10^{12} \mathrm{~mol} \mathrm{Ca}^{-1}$. Based on the measured DOC flux of $2.8 \times 10^{10} \mathrm{~mol} \mathrm{Ca}^{-1}$ (Table 3), this accounts for
Table 4. Estimates of soil DOC sources calculated using LoadEst (Runkel et al., 2004). Uncertainties represent 1 s.d. of the average for the 3 years of the record (2011-2013). Shallow and deep soil DOC fractions indicate the fraction of the total DOC load estimated to derive from shallow and deep soil DOC pools, respectively. Calculations were made based on shallow and deep soil DOM endmembers defined by observed maximum and minimum $S_{\mathrm{R}}$ and $a_{250} / a_{365}$ values.

\begin{tabular}{lrr}
\hline & $S_{\mathrm{R}}$ & $a_{250} / a_{365}$ \\
\hline shallow soil end-member & 0.81 & 4.94 \\
deep soil end-member & 1.17 & 8.12 \\
shallow soil DOC fraction & $0.611 \pm 0.018$ & $0.638 \pm 0.014$ \\
deep soil DOC fraction & $0.459 \pm 0.036$ & $0.364 \pm 0.015$ \\
\hline
\end{tabular}

$0.25 \%$ of NPP. Quantifying the annual POC flux is complicated by the very limited data set available $(n=29$, with 26 values from the 2013 early freshet period and 3 values during low discharge in 2010 and 2011); however, a first-order estimate of POC flux based on these data using LoadEst is $\sim 1 \times 10^{10} \mathrm{~mol} \mathrm{Ca}^{-1}$, i.e., $\sim 0.1 \%$ of NPP. This is likely an 
overestimate, as the limited POC training data set is biased towards the early freshet period, when POC concentrations are relatively high while discharge is not yet at peak values; thus, extrapolating to peak discharge may overestimate high discharge POC concentrations. Furthermore, some portion of POC derives from petrogenic OC (Voss, 2014), not recently living vegetation, thus a correction could be applied to the calculated POC flux based on POC radiocarbon ages, which would further reduce the flux of POC derived from recent NPP (Galy et al., 2015). In addition, widely varying values of NPP in the Fraser basin are available in the literature. For instance, Liu et al. (2002) report NPP of 189 and $215 \mathrm{~g} \mathrm{C} \mathrm{m}^{-2} \mathrm{a}^{-1}$ for the Pacific Maritime and Montane Cordillera ecozones, respectively, within the basin, corresponding to $<50 \%$ of the value of Ludwig et al. (1996) used for our calculations. Though beyond the scope of this study, the issue of basin-scale NPP estimates clearly warrants careful reassessment.

Accepting these uncertainties, it is clear that DOC dominates the export of terrestrial NPP in the Fraser basin, and annual DOC+POC fluxes transfer $0.25-0.35 \%$ of total NPP in the Fraser basin to the coastal ocean. Based on NPP and DOC and POC flux data presented by Ludwig et al. (1996), such a proportion of basin NPP exported as DOC $+\mathrm{POC}$ is typical, with most large rivers exporting $0.3-0.5 \%$ of NPP (e.g., Columbia: $0.2 \%$; Rhine: $0.3 \%$, Mississippi: $0.3 \%$, St. Lawrence: $0.4 \%$, Mackenzie: $0.5 \%$, Yukon: $0.5 \%$, Congo: $0.5 \%)$. The DOC yield of the Fraser River is also not exceptional for its runoff relative to other North American rivers (Spencer et al., 2013). Subtle differences in DOC export efficiency are likely obscured within this broad assessment; however, it is possible that the limited lake and reservoir area in the Fraser basin, which shortens DOC residence time and therefore limits the opportunity for heterotrophic consumption, may result in relatively efficient DOC export in this basin.

In light of anticipated future changes in regional climate and basin hydrology including a shift towards relatively more rain and less snow, an earlier onset of spring melting producing the freshet, and a rise in annual average air temperature, it is possible that DOM export from the Fraser River may change. Higher temperatures throughout the year may cause higher microbial activity in soils, leading to decreased inputs of soil DOM to streams. A shift towards more raindominated precipitation will cause river water temperatures to increase, which may promote increased microbial consumption of DOM in the aquatic realm. The dampening of the onset of the spring freshet may have the most significant impact, by drawing out the flushing of soil DOM over a longer period of time. This will increase the residence time of DOM in the river, providing greater opportunity for consumption of DOM before it reaches the coastal ocean. Thus future changes in climate are likely to decrease the total flux of DOM in the Fraser River.
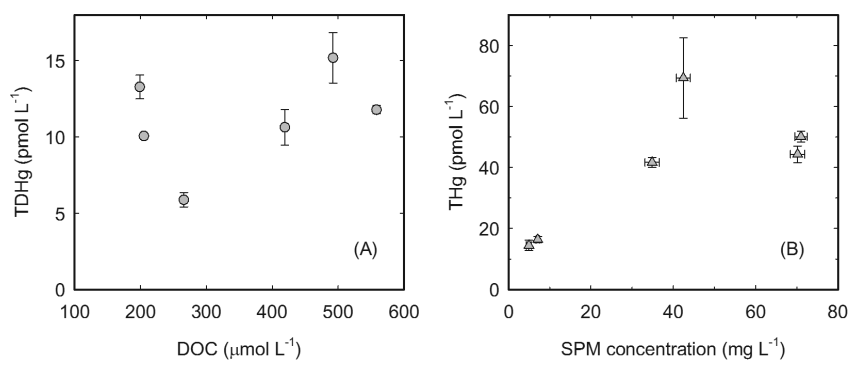

Figure 9. (a) Total dissolved mercury and DOC concentrations across the early freshet in 2013 were weakly correlated $\left(r^{2}=0.15\right)$. (b) Total $\mathrm{Hg}$ concentration (unfiltered) is positively correlated with SPM concentration $\left(r^{2}=0.51\right)$.

\subsection{Early freshet mercury dynamics}

Changes in dissolved and total $\mathrm{Hg}$ concentrations were examined as a possible consequence of the significant changes in DOC concentration during the early freshet period. Although sampling for dissolved, total, and sedimentary $\mathrm{Hg}$ was not as comprehensive as that for $\mathrm{OM}$ and other dissolved species, this contemporaneous data set allows for an initial assessment of $\mathrm{Hg}$ dynamics in an understudied watershed. Previous studies have identified a strong correlation between DOC concentration and TDHg concentration (e.g., Dittman et al., 2010; Schuster et al., 2011; Riscassi and Scanlon, 2011; Shanley et al., 2008), including during snowmelt (Shanley et al., 2002; Schuster et al., 2008; Demers et al., 2010), resulting from the association of $\mathrm{Hg}$ with DOM functional groups, particularly reduced sulfur moieties (Gerbig et al., 2011). The TDHg concentrations in the Fraser River during the early freshet period, however, are not clearly correlated with DOC concentration (Fig. 9a). In small headwater tributaries of the Hudson River (Burns et al., 2012), streams in northern New England (Dittman et al., 2010), and the Yukon River (Schuster et al., 2011), the TDHg concentration observed for a given DOC concentration is generally lower than our observations for the Fraser. In particular, TDHg concentrations on 30 March $\left(10.1 \mathrm{pmol} \mathrm{L}^{-1}\right)$ and 3 April $\left(13.3 \mathrm{pmol} \mathrm{L}^{-1}\right)$ are significantly higher than those predicted based on these previous studies. While the size of this data set is limited, the concentration changes are sufficiently large to indicate that processes in addition to changes in DOC concentration are likely required to explain the data.

The DOM optical property data demonstrated that the composition of DOM varies during the early freshet period; thus it is possible that distinct types of DOM bind dissolved Hg more or less strongly (Haitzer et al., 2003). While the relevant compositional characteristics may not be reflected in the optical property data, the lack of correlation between TDHg concentration and DOM optical properties does not support this explanation. To properly investigate this hypothesis, the bulk sulfur content of DOM should be analyzed, or 
specific sulfur-bearing functional groups quantified via highresolution mass spectrometry or X-ray spectroscopy.

The concentrations of total $\mathrm{Hg}$ in both dissolved and suspended material may provide further insight. The marked increase in $\mathrm{THg}$ concentrations over the early freshet period corresponds to an increase in the suspended sediment concentration (Fig. 9b), demonstrating that when suspended sediment concentrations rise above base flow levels, sediments contribute the majority of the $\mathrm{THg}$ load.

Regarding the TDHg concentrations, it is possible that the exchange of $\mathrm{Hg}$ between solid and dissolved phases changes with changes in SPM concentration. The apparent distribution coefficient ( $K_{\mathrm{d}}^{\prime}$ in units of $\mathrm{L} \mathrm{kg}^{-1}$ ) of $\mathrm{Hg}$ is defined as

$K_{\mathrm{d}}^{\prime}=\mathrm{THg}(\mathrm{SPM}) / \mathrm{TDHg}$

and quantifies the proportion of $\mathrm{Hg}$ present in solid vs. dissolved form. The calculated $\log \left(K_{\mathrm{d}}^{\prime}\right)$ values for the six time points sampled during the early freshet vary between 4.5 and 4.9, which are within the range of observations in other rivers (e.g., Hurley et al., 1998; Babiarz et al., 2012; Naik and Hammerschmidt, 2011). The significant decrease in SPM OC content during the early freshet may affect the affinity of $\mathrm{Hg}$ for the solid phase; i.e., higher SPM OC content may enhance sorption of dissolved $\mathrm{Hg}$. However, we do not observe a correlation between $\mathrm{Hg} K_{\mathrm{d}}^{\prime}$ and SPM \%OC. Thus it appears that other processes (such as changes in the chemical composition of DOM or POM) or synergistic effects are responsible for the trends observed in dissolved and particulate $\mathrm{Hg}$ during the Fraser River early freshet period. The most practical first step towards better understanding of $\mathrm{Hg}$ dynamics in this system is to generate a larger data set of TDHg concentrations.

Mercury-assisted gold mining in British Columbia, which involved the mobilization of $\sim 58 \times 10^{6} \mathrm{~m}^{3}$ of sediment in the central Fraser basin (Nelson and Church, 2012), has been proposed as the source of elevated $\mathrm{Hg}$ concentrations found in delta and lake sediments across the basin (Hales, 2000; Gallagher et al., 2003; Johannessen et al., 2005). Although the majority of the Hg contamination was most likely removed from the basin within decades due to its preferential association with rapidly mobilized fine-grained (OC-rich) sediments, the ongoing transport of mining-mobilized sediment through the basin (Nelson and Church, 2012) creates the potential for continued contamination.

In order to assess whether the $\mathrm{Hg}$ load of the Fraser River is elevated from possible legacy gold mining contamination or other pollution, we have estimated the expected Hg deposition flux assuming $\mathrm{Hg}$ is entirely derived from deposition of atmospheric aerosols and plant material. Soluble $\mathrm{Hg}^{2+}$ in precipitation constitutes wet deposition, while $\mathrm{Hg}$ derived from vegetation can be characterized as a combination of throughfall (adsorbed $\mathrm{Hg}$ on the surfaces of plant tissues) and litterfall (Hg within plant tissues; Graydon et al., 2008). Total deposition is the sum of wet and dry deposition. Dry deposition can be expressed as the sum of throughfall and litterfall, less open wet deposition if throughfall is determined by direct measurement of $\mathrm{Hg}$ on plant surfaces, which includes $\mathrm{Hg}$ from precipitation. Wet deposition was estimated using precipitation data from the Mercury Deposition Network (http://nadp.sws.uiuc.edu/mdn), which includes six stations near the Fraser River watershed: the Olympic Peninsula in Washington (WA03; 48.2892, -124.6519), Seattle, Washington (WA18; 47.6843, -122.2588), Glacier National Park (MT05; 48.5102, -113.9970), near Edmonton, Alberta (AB14; 53.3016, -114.2016), Vancouver, British Columbia (BC06; 49.1000, -123.1700), and the Strait of Georgia, British Columbia (BC16; 48.7753, - 123.1281). The precipitation $\mathrm{Hg}$ concentration records at these sites were weighted by precipitation amount to determine the average concentration at each site, which ranged from $2.8-8.7 \mathrm{ng} \mathrm{Hg} \mathrm{L}^{-1}$. The mean for all six sites was $4.8 \pm 0.3 \mathrm{ng} \mathrm{Hg} \mathrm{L}^{-1}$. Adopting this value as the $\mathrm{Hg}$ concentration of precipitation in the Fraser basin, which receives $742 \mathrm{~mm}$ of precipitation annu-

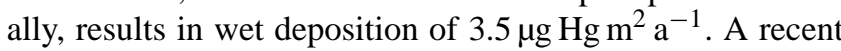
study by Graydon et al. (2008) in a remote area of northwestern Ontario found throughfall in forested areas to be $2-4 \times$ greater than wet deposition, and litterfall of a similar magnitude to throughfall (i.e., a total dry deposition rate 3-7x greater than wet deposition). Assuming similar behavior in the mostly forested Fraser basin, we estimate a total deposition flux of 3.2-6.5 $\mathrm{t} \mathrm{Hg} \mathrm{a}^{-1}$.

The total Hg flux of the Fraser River can be roughly estimated based on our observed SPM Hg concentrations during the 2013 early freshet, which showed little variability (mean \pm 1 s.d.: $0.447 \pm 0.015 \mathrm{pmol} \mathrm{mg}^{-1}$ ). Given an average sediment flux in the Fraser River of $17 \mathrm{Mt} \mathrm{a}^{-1}$ (PeuckerEhrenbrink, 2009), we estimate a Fraser River Hg flux of $1.5 \mathrm{t} \mathrm{Hg} \mathrm{a}^{-1}$. This is necessarily a first-order estimate, as SPM concentration and THg are not perfectly correlated in our data set, indicating that other factors play an important role in $\mathrm{Hg}$ export. However, this value is $24-47 \%$ of total $\mathrm{Hg}$ deposition, which represents a watershed delivery efficiency that is similar to or somewhat higher than other temperate watersheds (Brigham et al., 2009; Swain et al., 1992). It is therefore difficult to determine from these data whether there is a significant source of $\mathrm{Hg}$ beyond atmospheric deposition to the Fraser River. As the potential additional sources of $\mathrm{Hg}$ to the Fraser River, including natural weathering, legacy mining contamination, and contemporary pollution, do not elevate the $\mathrm{Hg}$ load beyond what is deposited by the atmosphere, it appears that soils and sediments within the basin are accumulating $\mathrm{Hg}$ and/or releasing a portion of the deposited $\mathrm{Hg}$ back to the atmosphere. 


\section{Conclusions}

This study has demonstrated for the first time the rapid shift in DOC and POC concentration and DOM and POM composition during the rising limb of the spring freshet of the Fraser River, as well as full annual trends in DOC concentration and DOM composition. DOM optical properties demonstrate that during the early spring freshet, as well as during the fall, DOM shifts to a composition consistent with increasing proportions of fresh plant-derived DOM (higher molecular weight, higher aromaticity; e.g., Fellman et al., 2009, 2010; Wickland et al., 2007), as well as highly aromatic black carbon (Jaffé et al., 2013), relative to microbially degraded sources of DOM (lower molecular weight, lower aromaticity). These trends demonstrate the hydrologic control of OM dynamics in a snowmelt-dominated river basin and suggests the importance of limited terrestrial water storage to DOM export. The rapid changes in DOM dynamics observed in the Fraser River underscore the utility of optical sensors, which could be deployed across a basin to generate time series of spatially resolved DOM behavior for process studies and flux estimates.

Concurrent dissolved and particulate $\mathrm{Hg}$ samples during the early freshet suggest DOM-Hg dynamics in the Fraser River that are distinct from what has been observed in other rivers, with apparently weaker control of dissolved $\mathrm{Hg}$ by DOC concentration. Future work on $\mathrm{Hg}$ in the Fraser River should focus on multiple metrics of DOM composition (e.g., molecular and elemental) as well as a data set covering a wider range of DOC concentrations and hydrologic conditions.

The characterization of time-varying DOM dynamics in this study adds to the understanding of hydrologic vs. biogeochemical controls on aquatic DOM cycling by revealing seasonal trends in an intermediate-sized temperate, forested river basin. Previous work has focused primarily on small headwater and mountain streams and large tropical and Arctic basins. The distinct climatic and hydrologic conditions of the Fraser basin (notably its snowmelt-dominated hydrology and minimal natural or anthropogenic impoundments) result in a DOC yield similar to that of the large Arctic Yukon River, despite its less extreme hydrograph. The high yield of DOC from the Fraser River relative to the highly impounded nearby Columbia River suggests that the relative lack of lakes and artificial reservoirs in the Fraser basin may be an important factor in transmitting terrestrial DOM to the coastal ocean.

Compared to large rivers globally, the Fraser River exports a typical proportion $(0.25-0.35 \%)$ of annual basin net primary productivity as DOC and POC, predominantly as DOC. This proportion is a fundamental metric for quantifying the relative efficiency of terrestrial $\mathrm{OC}$ export to the coastal ocean by diverse watersheds. At present, disagreement among published values of basin-scale NPP compli- cates a global assessment of fluvial NPP export; hence a careful reassessment of these values is critical.

Finally, as a relatively pristine river basin, the Fraser provides an important reference point for natural biogeochemical conditions that no longer exist in most mid- and lowlatitude watersheds of comparable size. Anthropogenic impacts from population growth and associated pollution, channel modification, and impoundment have significantly altered flows of carbon, nutrients, and sediment in large and small river basins globally over the past century, and in some areas continue at an accelerating rate. Studies such as this on a largely free-flowing temperate basin have broad implications for the understanding of natural fluvial processes which is not accessible elsewhere. A system such as the Fraser therefore provides a rare window into the impacts of large-scale processes, such as global climatic change, and sustained research on biogeochemical cycling in the Fraser River thus has the potential to demonstrate the response of natural aquatic systems to long-term changes in ecological conditions.

\section{The Supplement related to this article is available online at doi:10.5194/bg-12-5597-2015-supplement.}

Acknowledgements. This work was partially supported by a WHOI Ocean Ventures Fund award to BMV and NSF grants EAR-1226818 to BPE, OCE-0851015 to TIE, BPE, and VG, and OCE-0851101 to RGMS, and support to BPE from Jane and James Orr. Sediment EAIRMS analysis was performed by Carl Johnson at WHOI. Thanks to Michael Bothner and Michael Casso (USGS Woods Hole) for providing analytical support and use of the DMA-80 for sediment Hg measurements, to Scot Birdwhistell for assistance with ICPMS measurements, and to students and colleagues at the University of the Fraser Valley for sample collection. Two anonymous reviewers offered helpful comments that improved the final form of the manuscript.

Edited by: B. A. Bergamaschi

\section{References}

Agriculture and Agri-Food Canada: Length of Growing Season in British Columbia, available at: http://www.agr. gc.ca/eng/science-and-innovation/agricultural-practices/ climate/future-outlook/climate-change-scenarios/

length-of-growing-season-in-british-columbia, last access: 16 November 2014.

Amos, H. M., Jacob, D. J., Kocman, D., Horowitz, H. M., Zhang, Y., Dutkiewicz, S., Horvat, M., Corbitt, E. S., Krabbenhoft, D. P., and Sunderland, E. M.: Global biogeochemical implications of mercury discharges from rivers and sediment burial, Environ. Sci. Technol., 48, 9514-9522, doi:10.1021/es502134t, 2014. 
Aufdenkampe, A. K., Mayorga, E., Raymond, P. A., Melack, J. M., Doney, S. C., Alin, S. R., Aalto, R. E., and Yoo, K.: Riverine coupling of biogeochemical cycles between land, oceans, and atmosphere, Front. Ecol. Environ., 9, 53-60, doi:10.1890/100014, 2011

Babiarz, C., Hoffmann, S., Wieben, A., Hurley, J., Andren, A., Shafer, M., and Armstrong, D.: Watershed and discharge influences on the phase distribution and tributary loading of total mercury and methylmercury into Lake Superior, Environ. Pollut., 161, 299-310, doi:10.1016/j.envpol.2011.09.026, 2012.

Bagard, M.-L., Chabaux, F., Pokrovsky, O. S., Viers, J., Prokushkin, A. S., Stille, P., Rihs, S., Schmitt, A.-D., and Dupré, B.: Seasonal variability of element fluxes in two Central Siberian rivers draining high latitude permafrost dominated areas, Geochim. Cosmochim. Ac., 75, 3335-3357, doi:10.1016/j.gca.2011.03.024, 2011.

Battin, T. J.: Dissolved organic matter and its optical properties in a blackwater tributary of the upper Orinoco river, Venezuela, Org. Geochem., 28, 561-569, 1998.

Battin, T. J., Luyssaert, S., Kaplan, L. A., Aufdenkampe, A. K., Richter, A., and Tranvik, L. J.: The boundless carbon cycle, Nat. Geosci., 2, 598-600, doi:10.1038/ngeo618, 2009.

Bianchi, T. S., Garcia-Tigreros, F., Yvon-Lewis, S. A., Shields, M., Mills, H. J., Butman, D., Osburn, C., Raymond, P., Shank, G. C., DiMarco, S. F., Walker, N., Reese, B. K., MullinsPerry, R., Quigg, A., Aiken, G. R., and Grossman, E. L.: Enhanced transfer of terrestrially derived carbon to the atmosphere in a flooding event, Geophys. Res. Lett., 40, 116-122, doi:10.1029/2012gl054145, 2013.

Böhlke, J. K., Gwinn, C. J., and Coplen, T. B.: New reference materials for nitrogen-isotope-ratio measurements, Geostandard. Newslett., 17, 159-164, 1993.

Brigham, M. E., Wentz, D. A., Aiken, G. R., and Krabbenhoft, D. P.: Mercury cycling in stream ecosystems. 1 . Water column chemistry and transport, Environ. Sci. Technol., 43, 2720-2725, 2009.

Burns, D. A., Riva-Murray, K., Bradley, P. M., Aiken, G. R., and Brigham, M. E.: Landscape controls on total and methyl $\mathrm{Hg}$ in the upper Hudson River basin, New York, USA, J. Geophys. Res., 117, G01034, doi:10.1029/2011jg001812, 2012.

Burns, D. A., Aiken, G. R., Bradley, P. M., Journey, C. A., and Schelker, J.: Specific ultra-violet absorbance as an indicator of mercury sources in an Adirondack River basin, Biogeochemistry, 113, 451-466, doi:10.1007/s10533-012-9773-5, 2013.

Cai, W.-J.: Estuarine and coastal ocean carbon paradox: $\mathrm{CO}_{2}$ sinks or sites of terrestrial carbon incineration?, Annu. Rev. Mar. Sci., 3, 123-145, doi:10.1146/annurev-marine-120709-142723, 2011.

Cameron, E. M.: Hydrogeochemistry of the Fraser River, British Columbia: seasonal variation in major and minor components, J. Hydrol., 182, 209-225, 1996.

Cohen, B. The Cohen Commission of Inquiry into the Decline of Sockeye Salmon in the Fraser River. The Uncertain Future of Fraser River Sockeye, Volume 3, Chapter 2: Recommendations. Minister of Public Works and Government Services Canada, Ottawa, ON, 64 pp., 2012.

Cole, J. J. and Caraco, N. F.: Carbon in catchments: connecting terrestrial carbon losses with aquatic metabolism, Mar. Freshwater Res., 52, 101-110, 2001.

Coplen, T. B., Brand, W. A., Gehre, M., Gröning, M., Meijer, H. A. J., Toman, B., and Verkouteren, R. M.: New guide- lines for $\delta^{13} \mathrm{C}$ measurements, Anal. Chem., 78, 2439-2441, doi:10.1021/ac052027c, 2006.

Del Vecchio, R. and Blough, N. V.: Photobleaching of chromophoric dissolved organic matter in natural waters: kinetics and modeling, Mar. Chem., 78, 231-253, 2002.

Demers, J. D., Driscoll, C. T., and Shanley, J. B.: Mercury mobilization and episodic stream acidification during snowmelt: Role of hydrologic flow paths, source areas, and supply of dissolved organic carbon, Water Resour. Res., 46, W01511, doi:10.1029/2008WR007021, 2010.

Déry, S. J., Hernández-Henríquez, M. A., Owens, P. N., Parkes, M. W., and Petticrew, E. L.: A century of hydrological variability and trends in the Fraser River Basin, Environ. Res. Lett., 7, 024019, doi:10.1088/1748-9326/7/2/024019, 2012.

Dittman, J. A., Shanley, J. B., Driscoll, C. T., Aiken, G. R., Chalmers, A. T., Towse, J. E., and Selvendiran, P.: Mercury dynamics in relation to dissolved organic carbon concentration and quality during high flow events in three northeastern US streams, Water Resour. Res., 46, W07522, doi:10.1029/2009wr008351, 2010.

Dornblaser, M. M. and Striegl, R. G.: Nutrient (N, P) loads and yields at multiple scales and subbasin types in the Yukon River basin, Alaska, J. Geophys. Res., 112, G04S57, doi:10.1029/2006jg000366, 2007.

Dornblaser, M. M. and Striegl, R. G.: Suspended sediment and carbonate transport in the Yukon River Basin, Alaska: Fluxes and potential future responses to climate change, Water Resour. Res., 45, W06411, doi:10.1029/2008wr007546, 2009.

Downing, B. D., Pellerin, B. A., Bergamaschi, B. A., Saraceno, J. F., and Kraus, T. E. C.: Seeing the light: The effects of particles, dissolved materials, and temperature on in situ measurements of DOM fluorescence in rivers and streams, Limnol. Oceanogr.Meth., 10, 767-775, doi:10.4319/lom.2012.10.767, 2012.

Easthouse, K. B., Mulder, J., Christophersen, N., and Siep, H. M.: Dissolved organic carbon fractions in soil and stream water during variable hydrological conditions at Birkenes, southern Norway, Water Resour. Res., 28, 1585-1596, 1992.

Fellman, J. B., Hood, E., Edwards, R. T., and D'Amore, D. V.: Changes in the concentration, biodegradability, and fluorescent properties of dissolved organic matter during stormflows in coastal temperate watersheds, J. Geophys. Res., 114, G01021, doi:10.1029/2008jg000790, 2009.

Fellman, J. B., Spencer, R. G. M., Hernes, P. J., Edwards, R. T., D'Amore, D. V., and Hood, E.: The impact of glacier runoff on the biodegradability and biochemical composition of terrigenous dissolved organic matter in near-shore marine ecosystems, Mar. Chem., 121, 112-122, doi:10.1016/j.marchem.2010.03.009, 2010.

Fleck, J. A., Gill, G., Bergamaschi, B. A., Kraus, T. E. C., Downing, B. D., and Alpers, C. N.: Concurrent photolytic degradation of aqueous methylmercury and dissolved organic matter, Sci. Total Environ., 484, 263-275, doi:10.1016/j.scitotenv.2013.03.107, 2014.

Froehlich, K., Kralik, M., Papesch, W., Rank, D., Scheifinger, H., and Stichler, W.: Deuterium excess in precipitation of Alpine regions - moisture recycling, Isot. Environ. Healt. S., 44, 61-70, doi:10.1080/10256010801887208, 2008.

Gallagher, L., Macdonald, R. W., and Paton, D. W.: The historical record of metals in sediments from six lakes in the Fraser 
River Basin, British Columbia, Water Air Soil Poll., 152, 257278, 2003.

Galy, V., Peucker-Ehrenbrink, B., and Eglinton, T.: Global carbon export from the terrestrial biosphere controlled by erosion, Nature, 521, 204-207, doi:10.1038/nature14400, 2015.

Gangloff, S., Stille, P., Pierret, M.-C., Weber, T., and Chabaux, F.: Characterization and evolution of dissolved organic matter in acidic forest soil and its impact on the mobility of major and trace elements (case of the Strengbach watershed), Geochim. Cosmochim. Ac., 130, 21-41, doi:10.1016/j.gca.2013.12.033, 2014.

Gerbig, C. A., Ryan, J. N., and Aiken, G. R.: The effects of dissolved organic matter on mercury biogeochemistry, in: Environmental Chemistry and Toxicology of Mercury, edited by: Liu, G., Cai, Y., and O'Driscoll, N., John Wiley \& Sons Inc., Hoboken, NJ, 259-292, 2011.

Graydon, J. A., St. Louis, V. L., Hintelmann, H., Lindberg, S. E., Sandilands, K. A., Rudd, J. W. M., Kelly, C. A., Hall, B. D., and Mowat, L. D.: Long-term wet and dry deposition of total and methyl mercury in the remote boreal ecoregion of Canada, Environ. Sci. Technol., 42, 8345-8351, doi:10.1021/es801056j, 2008.

Haitzer, M., Aiken, G. R., and Ryan, J. N.: Binding of mercury(II) to dissolved organic matter: The role of the mercuryto-DOM concentration ratio, Environ. Sci. Technol., 36, 35643570, doi:10.1021/es025699i, 2002.

Haitzer, M., Aiken, G. R., and Ryan, J. N.: Binding of mercury(II) to aquatic humic substances: Influence of $\mathrm{pH}$ and source of humic substances, Environ. Sci. Technol., 37, 2436-2441, doi:10.1021/es026291o, 2003.

Hales, W. J.: Impact of human activity on deltaic sedimentation, marshes of the Fraser River delta, British Columbia, PhD thesis, Geography, University of British Columbia, Vancouver, BC, 187 pp., 2000.

Hammerschmidt, C. R., Bowman, K. L., Tabatchnick, M. D., and Lamborg, C. H.: Storage bottle material and cleaning for determination of total mercury in seawater, Limnol. Oceanogr.-Meth., 9, 426-431, doi:10.4319/lom.2011.9.426, 2011.

Holmes, R. M., McClelland, J. W., Raymond, P. A., Frazer, B. B., Peterson, B. J., and Stieglitz, M.: Lability of DOC transported by Alaskan rivers to the Arctic Ocean, Geophys. Res. Lett., 35, L03402, doi:10.1029/2007g1032837, 2008.

Holmes, R. M., McClelland, J. W., Peterson, B. J., Tank, S. E., Bulygina, E., Eglinton, T. I., Gordeev, V. V., Gurtovaya, T. Y., Raymond, P. A., Repeta, D. J., Staples, R., Striegl, R. G., Zhulidov, A. V., and Zimov, S. A.: Seasonal and annual fluxes of nutrients and organic matter from large rivers to the Arctic Ocean and surrounding seas, Estuaries Coasts, 35, 369-382, doi:10.1007/s12237-011-9386-6, 2012.

Hope, D., Billett, M. F., and Cresser, M. S.: A review of the export of carbon in river water: Fluxes and processes, Environ. Pollut., 84, 301-324, 1994.

Hurley, J. P., Cowell, S. E., Shafer, M. M., and Hughes, P. E.: Partitioning and transport of total and methyl mercury in the lower Fox River, Wisconsin, Environ. Sci. Technol., 32, 1424-1432, 1998.

IAEA: Reference and intercomparison materials for stable isotopes of light elements, IAEA-TECDOC-825, 5th IAEA Meeting on Stable Isotope Standards and Intercomparison Materials, Vienna, Austria, 1-3 December 1993, 159 pp., 1995.
Jaffé, R., Ding, Y., Niggemann, J., Vähätalo, A. V., Stubbins, A., Spencer, R. G. M., Campbell, J., and Dittmar, T.: Global charcoal mobilization from soils via dissolution and riverine transport to the oceans, Science, 340, 345-347, doi:10.1126/science.1231476, 2013.

Johannessen, S. C., MacDonald, R. W., and Eek, K. M.: Historical trends in mercury sedimentation and mixing in the strait of Georgia, Canada, Environ. Sci. Technol., 39, 4361-4368, doi:10.1021/es040535i, 2005.

Keil, R., Salemme, K., Forrest, B., Neibauer, J., and Logsdon, M.: Differential presence of anthropogenic compounds dissolved in the marine waters of Puget Sound, WA and Barkley Sound, BC, Mar. Pollut. Bull., 62, 2404-2411, doi:10.1016/j.marpolbul.2011.08.029, 2011.

Kelly, B. C., Ikonomou, M. G., Higgs, D. A., Oakes, J., and Dubetz, C.: Mercury and other trace elements in farmed and wild salmon from British Columbia, Canada, Environ. Toxicol. Chem., 27, 1361-1370, 2008.

Laraque, A., Castellanos, B., Steiger, J., Lòpez, J. L., Pandi, A., Rodriguez, M., Rosales, J., Adèle, G., Perez, J., and Lagane, C.: A comparison of the suspended and dissolved matter dynamics of two large inter-tropical rivers draining into the Atlantic Ocean: the Congo and the Orinoco, Hydrol. Processes, 27, 2153-2170, doi:10.1002/hyp.9776, 2013.

Liu, J., Chen, J. M., Cihlar, J., and Chen, W.: Net primary productivity mapped for Canada at 1-km resolution, Global Ecol. Biogeogr., 11, 115-129, doi:10.1046/j.1466-822X.2002.00278.x, 2002.

Lloret, E., Dessert, C., Pastor, L., Lajeunesse, E., Crispi, O., Gaillardet, J., and Benedetti, M. F.: Dynamic of particulate and dissolved organic carbon in small volcanic mountainous tropical watersheds, Chem. Geol., 351, 229-244, doi:10.1016/j.chemgeo.2013.05.023, 2013.

Ludwig, W., Probst, J.-L., and Kempe, S.: Predicting the oceanic input of organic carbon by continental erosion, Global Biogeochem. Cy., 10, 23-41, 1996.

MacDonald, D., Sinclair, J., Crawford, M., Prencipe, H., and Meneghetti, M.: The Cohen Commission of Inquiry into the Decline of Sockeye Salmon in the Fraser River, Technical Report 2: Potential effects of contaminants on Fraser River sockeye salmon, MacDonald Environmental Sciences Ltd., Vancouver, BC, 164 pp., 2011.

Mann, P. J., Davydova, A., Zimov, N., Spencer, R. G. M., Davydov, S., Bulygina, E., Zimov, S., and Holmes, R. M.: Controls on the composition and lability of dissolved organic matter in Siberia's Kolyma River basin, J. Geophys. Res., 117, G01028, doi:10.1029/2011jg001798, 2012.

Meybeck, M. and Ragu, A.: GEMS-GLORI world river discharge database, Université Pierre et Marie Curie, Paris, doi:10.1594/PANGAEA.804574, 2012.

Michalzik, B., Kalbitz, K., Park, J.-H., Solinger, S., and Matzner, E.: Fluxes and concentrations of dissolved organic carbon and nitrogen: A synthesis for temperate forests, Biogeochemistry, 52, 173-205, 2001.

Michalzik, B., Tipping, E., Mulder, J., Lancho, J. F. G., Matzner, E., Bryant, C. L., Clarke, N., Lofts, S., and Esteban, M. A. V.: Modelling the production and transport of dissolved organic carbon in forest soils, Biogeochemistry, 66, 241-264, 2003. 
Mills, R. T. E., Tipping, E., Bryant, C. L., and Emmett, B. A.: Longterm organic carbon turnover rates in natural and semi-natural topsoils, Biogeochemistry, 118, 257-272, doi:10.1007/s10533013-9928-z, 2014.

Morrison, J., Quick, M. C., and Foreman, M. G. G.: Climate change in the Fraser River watershed: flow and temperature projections, J. Hydrol., 263, 230-244, 2002.

Naik, A. P. and Hammerschmidt, C. R.: Mercury and trace metal partitioning and fluxes in suburban Southwest Ohio watersheds, Water Res., 45, 5151-5160, doi:10.1016/j.watres.2011.07.023, 2011

Nelson, A. D. and Church, M.: Placer mining along the Fraser River, British Columbia: The geomorphic impact, Geol. Soc. Am. Bull., 124, 1212-1228, doi:10.1130/b30575.1, 2012.

O’Donnell, J. A., Aiken, G. R., Kane, E. S., and Jones, J. B.: Source water controls on the character and origin of dissolved organic matter in streams of the Yukon River basin, Alaska, J. Geophys. Res., 115, G03025, doi:10.1029/2009jg001153, 2010.

Oswald, C. J. and Branfireun, B. A.: Antecedent moisture conditions control mercury and dissolved organic carbon concentration dynamics in a boreal headwater catchment, Water Resour. Res., 50, 6610-6627, doi:10.1002/2013WR014736, 2014.

Patterson, C. C. and Settle, D. M.: The reduction of orders of magnitude errors in lead analyses of biological material and natural waters by evaluating and controlling the extent and sources of industrial lead contamination introduced during sample collection, handling and analysis, in: Accuracy in Trace Analysis: Sampling, Sample Handling, and Analysis, edited by: LaFleur, P. D., US National Bureau of Standards Special Publication 422, Washington DC, 321-351, 1976.

Pereira, R., Isabella Bovolo, C., Spencer, R. G. M., Hernes, P. J., Tipping, E., Vieth-Hillebrand, A., Pedentchouk, N., Chappell, N. A., Parkin, G., and Wagner, T.: Mobilization of optically invisible dissolved organic matter in response to rainstorm events in a tropical forest headwater river, Geophys. Res. Lett., 41, 12021208, doi:10.1002/2013g1058658, 2014.

Peucker-Ehrenbrink, B.: Land2Sea database of river drainage basin sizes, annual water discharges, and suspended sediment fluxes, Geochem. Geophy. Geosy., 10, Q06014, doi:10.1029/2008gc002356, 2009.

Peuravuori, J. and Pihlaja, K.: Molecular size distribution and spectroscopic properties of aquatic humic substances, Anal. Chim. Acta, 337, 133-149, 1997.

Qi, H., Coplen, T. B., Geilmann, H., Brand, W. A., and Böhlke, J. $\mathrm{K}$.: Two new organic reference materials for $\delta^{13} \mathrm{C}$ and $\delta^{15} \mathrm{~N}$ measurements and a new value for the $\delta^{13} \mathrm{C}$ of NBS 22 oil, Rapid Commun. Mass Sp., 17, 2483-2487, doi:10.1002/rcm.1219, 2003.

Raymond, P. A. and Saiers, J. E.: Event controlled DOC export from forested watersheds, Biogeochemistry, 100, 197-209, doi:10.1007/s10533-010-9416-7, 2010.

Raymond, P. A., McClelland, J. W., Holmes, R. M., Zhulidov, A. V., Mull, K., Peterson, B. J., Striegl, R. G., Aiken, G. R., and Gurtovaya, T. Y.: Flux and age of dissolved organic carbon exported to the Arctic Ocean: A carbon isotopic study of the five largest arctic rivers, Global Biogeochem. Cy., 21, GB4011, doi:10.1029/2007gb002934, 2007.

Riche, O., Johannessen, S. C., and Macdonald, R. W.: Why timing matters in a coastal sea: Trends, variability and tipping points in the Strait of Georgia, Canada, J. Marine Syst., 131, 36-53, doi:10.1016/j.jmarsys.2013.11.003, 2014.

Riscassi, A. L. and Scanlon, T. M.: Controls on stream water dissolved mercury in three mid-Appalachian forested headwater catchments, Water Resour. Res., 47, W12512, doi:10.1029/2011WR010977, 2011.

Rochelle-Newall, E. J. and Fisher, T. R.: Production of chromophoric dissolved organic matter fluorescence in marine and estuarine environments: an investigation into the role of phytoplankton, Mar. Chem., 77, 7-21, 2002.

Runkel, R. L., Crawford, C. G., and Cohn, T. A.: Load Estimator (LOADEST): A FORTRAN program for estimating constituent loads in streams and rivers, US Geological Survey techniques and methods Book 4, chapter A5, Reston, VA, 2004.

Sandford, R. C., Hawkins, J. M. B., Bol, R., and Worsfold, P. J.: Export of dissolved organic carbon and nitrate from grassland in winter using high temporal resolution, in situ UV sensing, Sci. Total Environ., 456-457, 384-391, doi:10.1016/j.scitotenv.2013.02.078, 2013.

Saraceno, J. F., Pellerin, B. A., Downing, B. D., Boss, E., Bachand, P. A. M., and Bergamaschi, B. A.: High-frequency in situ optical measurements during a storm event: Assessing relationships between dissolved organic matter, sediment concentrations, and hydrologic processes, J. Geophys. Res., 114, G00F09, doi:10.1029/2009jg000989, 2009.

Schuster, P. F., Shanley, J. B., Marvin-Dipasquale, M., Reddy, M. M., Aiken, G. R., Roth, D. A., Taylor, H. E., Krabbenhoft, D. P., and DeWild, J. F.: Mercury and organic carbon dynamics during runoff episodes from a Northeastern USA watershed, Water Air Soil Poll., 187, 89-108, doi:10.1007/s11270-007-9500-3, 2008.

Schuster, P. F., Striegl, R. G., Aiken, G. R., Krabbenhoft, D. P., Dewild, J. F., Butler, K., Kamark, B., and Dornblaser, M.: Mercury export from the Yukon River Basin and potential response to a changing climate, Environ. Sci. Technol., 45, 9262-9267, doi:10.1021/es202068b, 2011

Shanley, J. B., Schuster, P. F., Reddy, M. M., Roth, D. A., Taylor, H. E., and Aiken, G. R.: Mercury on the move during snowmelt in Vermont, Eos, 83, 45-48, doi:10.1029/2002EO000031, 2002.

Shanley, J. B., Alisa Mast, M., Campbell, D. H., Aiken, G. R., Krabbenhoft, D. P., Hunt, R. J., Walker, J. F., Schuster, P. F., Chalmers, A., Aulenbach, B. T., Peters, N. E., MarvinDiPasquale, M., Clow, D. W., and Shafer, M. M.: Comparison of total mercury and methylmercury cycling at five sites using the small watershed approach, Environ. Pollut., 154, 143-154, doi:10.1016/j.envpol.2007.12.031, 2008.

Shrestha, R. R., Schnorbus, M. A., Werner, A. T., and Berland, A. J.: Modelling spatial and temporal variability of hydrologic impacts of climate change in the Fraser River basin, British Columbia, Canada, Hydrol. Process., 26, 1840-1860, doi:10.1002/hyp.9283, 2012.

Spencer, R. G. M., Hernes, P. J., Ruf, R., Baker, A., Dyda, R. Y., Stubbins, A., and Six, J.: Temporal controls on dissolved organic matter and lignin biogeochemistry in a pristine tropical river, Democratic Republic of Congo, J. Geophys. Res., 115, G03013, doi:10.1029/2009jg001180, 2010.

Spencer, R. G. M., Butler, K. D., and Aiken, G. R.: Dissolved organic carbon and chromophoric dissolved organic matter properties of rivers in the USA, J. Geophys. Res., 117, G03001, doi:10.1029/2011jg001928, 2012. 
Spencer, R. G. M., Aiken, G. R., Dornblaser, M. M., Butler, K. D., Holmes, R. M., Fiske, G., Mann, P. J., and Stubbins, A.: Chromophoric dissolved organic matter export from US rivers, Geophys. Res. Lett., 40, 1575-1579, doi:10.1002/grl.50357, 2013.

Stedmon, C. A. and Markager, S.: Behaviour of the optical properties of coloured dissolved organic matter under conservative mixing, Estuar. Coast. Shelf S., 57, 973-979, doi:10.1016/s02727714(03)00003-9, 2003.

Stepanauskas, R., Moran, M. A., Bergamaschi, B. A., and Hollibaugh, J. T.: Sources, bioavailability, and photoreactivity of dissolved organic carbon in the Sacramento-San Joaquin River Delta, Biogeochemistry, 74, 131-149, doi:10.1007/s10533-0043361-2, 2005.

Striegl, R. G., Aiken, G. R., Dornblaser, M. M., Raymond, P. A., and Wickland, K. P.: A decrease in discharge-normalized DOC export by the Yukon River during summer through autumn, Geophys. Res. Lett., 32, L21413, doi:10.1029/2005g1024413, 2005.

Sun, L., Perdue, E. M., Meyer, J. L., and Weis, J.: Use of elemental composition to predict bioavailability of dissolved organic matter in a Georgia river, Limnol. Oceanogr., 42, 714-721, 1997.

Swain, E. B., Engstrom, D. R., Brigham, M. E., Henning, T. A., and Brezonik, P. L.: Increasing rates of atmospheric mercury deposition in midcontinental North America, Science, 257, 784-787, doi:10.1126/science.257.5071.784, 1992.

Swain, L. G.: Water quality assessment of the Fraser River at Hope (1979-2004), BC Ministry of Environment and Environment Canada, http://www.env.gov.bc.ca/wat/wq/quality/ hope/wq_fraser_riv_hope_2004.pdf (last access: 23 September 2015), 74 pp., 2007.

Townsend-Small, A., McClelland, J. W., Max Holmes, R., and Peterson, B. J.: Seasonal and hydrologic drivers of dissolved organic matter and nutrients in the upper Kuparuk River, Alaskan Arctic, Biogeochemistry, 103, 109-124, doi:10.1007/s10533010-9451-4, 2011.

US EPA: Method 1631, Revision E: Mercury in water by oxidation, purge, and trap, and cold vapor atomic fluorescence spectrometry, US EPA Office of Science and Technology, Washington DC, 38 pp., 2002.

US EPA: Method 7473, Mercury in solids and solutions by thermal decomposition, amalgamation, and atomic absorption spectrophotometry, Revision 0, US EPA Office of Science and Technology, Washington DC, 17 pp., 2007.

Valentine, K. W. G., Sprout, P. N., Baker, T. E., and Lawkulich, L. M. E. (Eds.): The Soil Landscapes of British Columbia, BC Ministry of Environment, Resource Analysis Branch, 1978.

Vold, T.: Soils in the Cariboo River Valley, B.C., with selected engineering interpretations, BC Ministry of Environment, Victoria, BC, 23 pp., 1979.

Voss, B. M.: Spatial and temporal dynamics of biogeochemical processes in the Fraser River, Canada: A coupled organic-inorganic perspective, PhD thesis, Marine Chemistry \& Geochemistry, MIT/WHOI, Woods Hole, USA, 276 pp., 2014.
Voss, B. M., Peucker-Ehrenbrink, B., Eglinton, T. I., Fiske, G., Wang, Z. A., Hoering, K. A., Montluçon, D. B., LeCroy, C., Pal, S., Marsh, S., Gillies, S. L., Janmaat, A., Bennett, M., Downey, B., Fanslau, J., Fraser, H., Macklam-Harron, G., Martinec, M., and Wiebe, B.: Tracing river chemistry in space and time: Dissolved inorganic constituents of the Fraser River, Canada, Geochim. Cosmochim. Ac., 124, 283-308, doi:10.1016/j.gca.2013.09.006, 2014.

Walling, D. E. and Foster, I. D. L.: Variations in the natural chemical concentration of river water during flood flows, and the lag effect: Some further comments, J. Hydrol., 26, 237-244, 1975.

Ward, N. D., Richey, J. E., and Keil, R. G.: Temporal variation in river nutrient and dissolved lignin phenol concentrations and the impact of storm events on nutrient loading to Hood Canal, Washington, USA, Biogeochemistry, 111, 629-645, doi:10.1007/s10533-012-9700-9, 2012.

Weishaar, J. L., Aiken, G. R., Bergamaschi, B. A., Fram, M. S., Fujii, R., and Mopper, K.: Evaluation of specific ultraviolet absorbance as an indicator of the chemical composition and reactivity of dissolved organic carbon, Environ. Sci. Technol., 37, 47024708, doi:10.1021/es030360x, 2003.

Whitfield, P. H. and Schreier, H.: Hysteresis in relationships between discharge and water chemistry in the Fraser River basin, British Columbia, Limnol. Oceanogr., 26, 1179-1182, 1981.

Wickland, K. P., Neff, J. C., and Aiken, G. R.: Dissolved organic carbon in Alaskan boreal forest: Sources, chemical characteristics, and biodegradability, Ecosystems, 10, 1323-1340, doi:10.1007/s10021-007-9101-4, 2007.

Wickland, K. P., Aiken, G. R., Butler, K., Dornblaser, M. M., Spencer, R. G. M., and Striegl, R. G.: Biodegradability of dissolved organic carbon in the Yukon River and its tributaries: Seasonality and importance of inorganic nitrogen, Global Biogeochem. Cy., 26, GB0E03, doi:10.1029/2012gb004342, 2012.

Writer, J. H., Leenheer, J. A., Barber, L. B., Amy, G. L., and Chapra, S. C.: Sewage contamination in the upper Mississippi River as measured by the fecal sterol, coprostanol, Water Res., 29, 14271436, 1995.

Yang, L. and Hur, J.: Critical evaluation of spectroscopic indices for organic matter source tracing via end member mixing analysis based on two contrasting sources, Water Res., 59, 80-89, doi:10.1016/j.watres.2014.04.018, 2014.

Zhao, Y., Krzic, M., Bulmer, C. E., and Schmidt, M. G.: Maximum bulk density of British Columbia forest soils from the Proctor Test: Relationships with selected physical and chemical properties, Soil Sci. Soc. Am. J., 72, 442-452, doi:10.2136/sssaj2007.0075, 2008.

Zheng, W., Liang, L., and Gu, B.: Mercury reduction and oxidation by reduced natural organic matter in anoxic environments, Environ. Sci. Technol., 46, 292-299, doi:10.1021/es203402p, 2012. 